\title{
室内環境に関する研究
}

\author{
嵐谷奎一 ${ }^{1)}$ ，秋山幸雄 ${ }^{1) ，}$ 欅田尚樹2) \\ 1)産業医科大学産業保健学部 $=807-8555$ 福岡県北九州市八幡西区医生ヶ丘 $1-1$ \\ ${ }^{2}$ 国立保健医療科学院 ₹351-0197 埼玉県和光市南2-3-6
}

\section{Study of indoor air pollution}

\author{
Keiichi ARASHIDANI ${ }^{1)}$, Yukio AKIYAMA ${ }^{1)}$ and Naoki KUNUGITA ${ }^{2)}$
}

\begin{abstract}
1)Department of Environmental Management, School of Health Sciences, University of Occupational and Environmental Health, Japan 1-1 Iseigaoka, Yahatanishi-ku, Kitakyushu City, Fukuoka 807-8555 Japan

2)Department of Environmental Health, National Institute of Public Health, 2-3-6 Minami,Wako City Saitama 351-0197 Japan

\section{要 旨}

1970年代より今日までの室内環境中の化学物質の種類, 濃度計測を中心とし発表された我が国の調査・研 究についてまとめた。2000年以前の調査・研究については, $\mathrm{NO}_{2}, \mathrm{CO}, \mathrm{CO}_{2}$, 粉塵を室内污染の中心として なされ，2000年以降は，シックハウス症候群などの室内に起因する疾病の原因対策の視点で，揮発性有機化 合物やアルデヒド類などの化学物質の調査, また化学物質過敏症調査や健康な住居環境構築のための調査・ 研究がなされてきている。
\end{abstract}

\begin{abstract}
We summarized about Japanese research reports according to chemical's kinds and concentrations in indoor air atmosphere from 1970 's to today. The study reports before 2000 were mainly carried out on indoor air pollution of $\mathrm{N}$ $\mathrm{O}_{2}, \mathrm{CO}, \mathrm{CO}_{2}$ and particle. The studies after 2000 were carried out on a relationship between sick building syndrome and chemicals. Therefore, studies were what measurement of volatile organic compounds and aldehydes, and about chemical sensitivity. We reviewed main researches in these many reports in Japan.
\end{abstract}

Key words: 室内環境 (Indoor environment)，化学物質 (chemicals)，化学物質過敏症 (chemical sensitivity)

\section{1.はじめに}

1960年頃からの高度経済成長を迎え，食・住を含 む生活様式全般に渡って，欧米型に変り，室内污染 に係る健康障害の問題が注目されるようになった。 特に, 最近のビル環境を含めて一般生活環境として, 高気密化による換気不足や新建材・冷暖房などの導 入, 室内用の殺虫剂などの使用, 室外からの排気ガ スや花粉などの大気污染物質の侵入, 食生活の変化, 精神的ストレスの増加にアレルギー保持者の増加な どによる健康問題が挙げられる。

最近の生活環境に起因して発症する疾病は従来型 の中毒学では解明できない複雑な機序によるが, 微 量化学物質によって神経系や免疫系の異常な变化に よる様々な健康影響を誘発している。生活環境に係

受付：2009年9月28日(Received：28 September 2009) 受理：2009年10月15日(Accepted：15 October 2009)
る健康問題は，その発生原因を特定することが難し い事が多い。

室内污染が大きく注目されたのは，1976年，米国 フィラデルフィア市で開催されたアメリカ在郷軍人 の大会での事象である。ホテルの空調機の冷房用冷 却塔の水にレジオネラ菌が増殖し, 室内空気へ供給 された。この為多くの中毒患者や死亡者が30数名之 なる惨事が発生した。この種々の症状を呈する現象 を広くシックビルディング症候群と称した。この原 因は家屋に由来し，これから離れると症状は軽減し， 消失する。しかし，これとは別に化学物質過敏症が 問題となってきた。これは, 室外に出ても排気ガス 等の化学物質などに反応して症状があり, この症状 は, ヘアースプレー, 香水, 芳香剤等々の化学物質 に反応して, 過敏状態となり, 多臓器に影響が生じ, 日常生活に支障をきたす。 
近年の生活環境中は多様化し, 家具, 衣類, 壁な ぞ物理的材料などから放散される化学物質が数百種 類にのぼり, 暖房, 調理や喫煙などが加わると, 4000 種以上の化学物質で污染されているといわれて いる。

最近我々の日常生活はビル, 住居などの建築物内 で80 90\%を過ごし ${ }^{1,22}$, 室内の空気質の良否, 室内 污染とヒト健康影響などが問題となってきた。この 様に, ビル・一般家庭室内の空気質, すなわち有害 化学物質の污染等が極めて重要な問題となり, 污染 物質の個人曝露の把握, 疾病などの調査と室内污染 低減は極めて重要な問題となってきている。

ここでは我が国における室内污染に係る注目され る発表を中心として年代順に記述する。

\section{2. 生活環境中に存在する化学物質}

ビル, 一般住宅や公共施設等の建築物内環境には, アルデヒド類を含む揮発性有機化合物 (VOCs), CO, $\mathrm{CO}_{2}, \mathrm{NOx}$, ラドン等の無機化合物, 粉塵やアスベ ストなどの浮遊粒子状物質及び微生物, ダ二, 花粉 等のアレルゲンなど極めて多数の物質が存在する。
また, 広義には, 温熱, 光, 騒音, 振動等々も重要 な要素である。

室内污染の原因物質は, 室内に多くは発生源があ るが，それ以外室外からの侵入によるもの屯ある。 室内に存在する污染物質と発生源之の関連について 示す(表1)。

特に, 室内污染之健康障害之の係りで問題とされ ている揮発性有機化合物之室内発生源を示す(表2)。

\section{2000 年以前の研究}

2000年以前の室内污染の研究は窒素酸化物を中心 に, $\mathrm{CO}, \mathrm{CO}_{2}$, 粉塵で, その後, VOCs, アルデヒ ド類が注目されてきた。

1970年代に入って, 室内環境の研究が本格的に始 まり, その中で長谷川ら $(1976)^{3)}$ はチャンバーテス 卜で, 暖房器具使用で窒素酸化物濃度推移を求め, いずれの器具とも $\mathrm{NO}_{2}, \mathrm{NO}$ 濃度とも $0.1 \mathrm{ppm}$ 超し， 特に対流型石油ストーブでは $1 \mathrm{ppm}$ を超す高值であっ た(図1)。

松村ら $(1981)^{4)}$ は大規模建築物内の $\mathrm{NO}_{2}$ 濃度を計 測し，一時間值の最高はオフィス $0.083 \mathrm{ppm，デパー}$

\section{表1 室内污染原因と代表的污染物質}

\begin{tabular}{|c|c|}
\hline 原因(発生源) & 代表的污染物質 \\
\hline \multicolumn{2}{|l|}{ 外気の進入 } \\
\hline 固定発生源 & 二酸化硫黄, 窒素酸化物, 一酸化炭素, 二酸化酸素, 炭化水素, \\
\hline 移動発生源 & アルデヒドなどのガス状物質 \\
\hline 戸外焼却 & 重金属類, 多環芳香族炭化水素 (PAH), \\
\hline 山火事 」 & ニトロアレーンなどの粒子状物質 \\
\hline 化学物質取扱い作業場 & 各種取扱い化学物質ならびにそれらの処理に伴う反応生物など \\
\hline 土壤 & ラドン, 微生物など \\
\hline 土砂の巻き上げ & 重金属類など \\
\hline 大気中での光化学反応など & オゾン, アルデヒド, ニトロアレーンなど \\
\hline \multicolumn{2}{|l|}{ 室内発生源 } \\
\hline \multicolumn{2}{|l|}{ 建物の構成材料 } \\
\hline コンクリート, 石材 & ラドン \\
\hline パーティクルボード, 合板 & ホルムアルデヒド \\
\hline $\begin{array}{l}\text { 断熱材 } \\
\text { 塗料 }\end{array}$ & $\begin{array}{l}\text { アスベスト, ガラス纎維, ロックウール, 重金属類, ホルムアルデヒドなど } \\
\text { 鉛, 有機溶剤 }\end{array}$ \\
\hline \multicolumn{2}{|l|}{ 建物内の施設 } \\
\hline 暖房, 調理などの燃焼器具 & $\begin{array}{l}\text { 一酸化炭素, 二酸化炭素, 窒素酸化物, 炭化水素, アルデヒド, } \\
\text { PAH, 粒子状物質など }\end{array}$ \\
\hline コピー機器 & オゾン, 粒子状物質 \\
\hline 水まわり & ラドン \\
\hline $\begin{array}{l}\text { ヒトやペットからの発散物 } \\
\text { ヒトの活動に伴う発散物 }\end{array}$ & 二酸化炭素, アンモニア, ニオイ物質, ふけ, ダニ, 微生物など \\
\hline 喫煙 & $\begin{array}{l}\text { 一酸化炭素, ニコチン, ニトロソアミン, ニオイ物質, アルデヒド, } \\
\text { PAH, 粒子状物質など }\end{array}$ \\
\hline エーロゾル噴霧 & 炭化水素, ニオイ物質 \\
\hline クリーニング & 有機塩素系化合物, 炭化水素, ニオイ物質 \\
\hline 衣服の収納（防虫剤使用） & パラ・ジクロロベンゼンなど \\
\hline シャワー & トリハロメタン \\
\hline 趣味（油絵，工芸など） & 有機溶剂, ニオイ物質, 粒子状物質 \\
\hline 線香 & ニオイ物質, PAH, 粒子状物質 \\
\hline 走行, カーテンの開閉など & 粒子状物質 \\
\hline
\end{tabular}

(松下) 
表2 家具・建材に含有される代表的な揮発性 有機化合物

\begin{tabular}{|c|c|}
\hline 家具接着剤 & 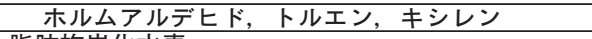 \\
\hline 建築資材 & 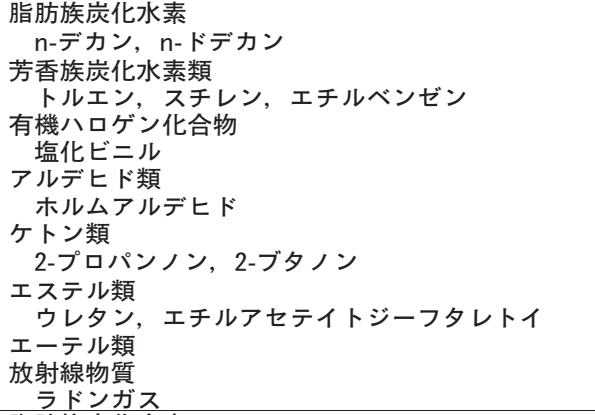 \\
\hline 粘着/接着剂 & 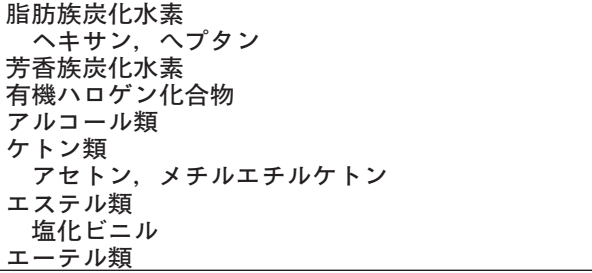 \\
\hline 家具・布製品 & 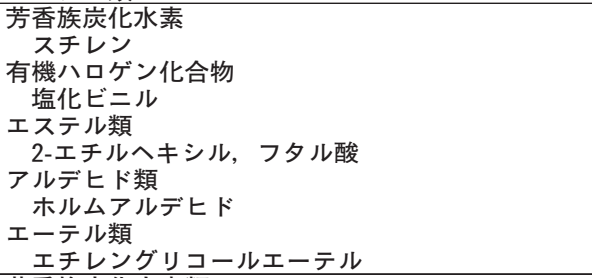 \\
\hline 塗料, スプレー & 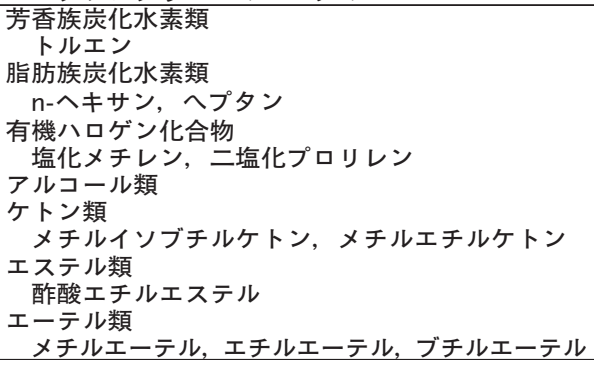 \\
\hline
\end{tabular}

（安藤, VOCの毒性アレルギーの臨床, 1998)

ト $0.050 \mathrm{ppm}$, 厨房 $0.108 \mathrm{ppm}$, 地下街0.173ppmで, 室内／室外比はオフィス $0.6 \sim 0.8$ ，デパート 0.6 ，廚

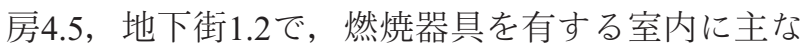

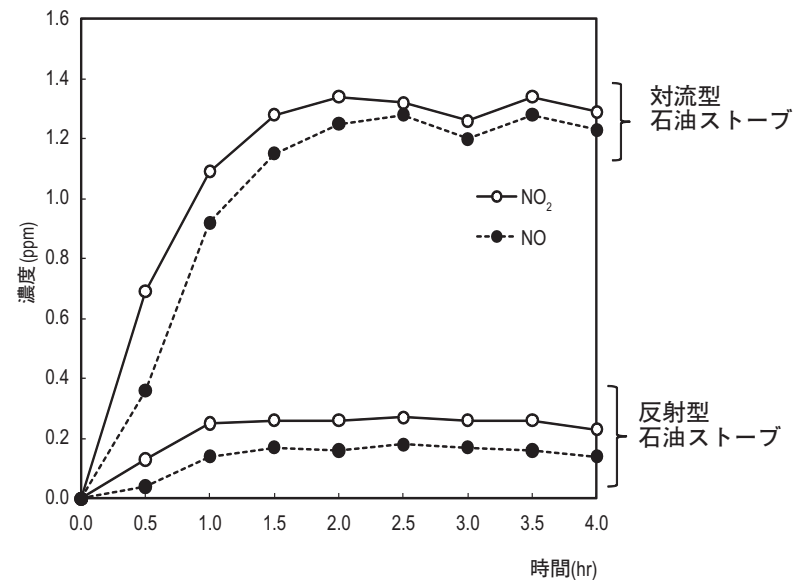

発生源があることを認めた。

なお，ビル管理法の対象の特定建築物 (床面積 $3,000 \mathrm{~m}^{2}$ 以上) の就業時間中の平均濃度值はオフィス $0.054 \mathrm{ppm}$ ，デパート $0.044 \mathrm{ppm}$ であった。

$\mathrm{NO}_{2}$ の様に発生源が多様で, かつヒト健康影響を 評価する上で，簡易でかつ個人曝露量が把握できる サンプラーが必要で, この視点から, 柳沢ら $(1980)^{5)}$ はパーソナル・サンプラーの開発を行った。 これにより, $\mathrm{NO}_{2}$ の気中濃度や個人曝露評価を飛躍 的に発展させる契機になった。

新田ら $\left.(1981)^{6}\right)$ は, 開発された $\mathrm{NO}_{2}$ フィルターバッ ジを用いて, 個人(24時間), 室内, 室外で $\mathrm{NO}_{2}$ 濃度 の計測し, 冬が秋に比べ高く, 特に室内の暖房器具 使用由来であることを認めた。

松木ら $(1985)^{7)}$ は東京都内之郊外及び北海道田園 地帯で $\mathrm{NO}_{2}$ 個人曝露量の計測を行った。明らかに季 節変動があり, 冬期は夏季の約 2 倍の曝露濃度で, 特に冬期非排気ストーブからの排出される $\mathrm{NO}_{2}$ の影 響を受けている。しかし， $\mathrm{NO}_{2}$ 個人曝露は家庭内で 能動・受動喫煙による影響をほとんど受けなかった。

村松 $(1986)^{8)}$ は, 冬期東京都内, 及び近郊の住宅 で化学物質の濃度を計測した。 $\mathrm{NO}_{2}$ 濃度は室外に比 ベ室内が高く, 特に, 1 時間值の最高は $0.3 \mathrm{ppm}$, 日 平均值の最高も $0.08 \mathrm{ppm}$ であった。反射型ストーブ (開放型)の住居で, $\mathrm{NO}_{2}$ 日平均值 $0.052 \sim 0.669 \mathrm{ppm}$, 1 時間値の最高は $0.300 \sim 0.500 \mathrm{ppm}$ 超えることああ り, また, FF式石油ストーブでは, 日平均值 0.023 $\mathrm{ppm}$ と低く, 1 時間值の最高は $0.23 \mathrm{ppm}$ であった。な お, 大気污染に係る環境基準の日平均值 $0.06 \mathrm{ppm}$ を 超える割合は全測定日数（27日）の約30～70\%という 結果であった。

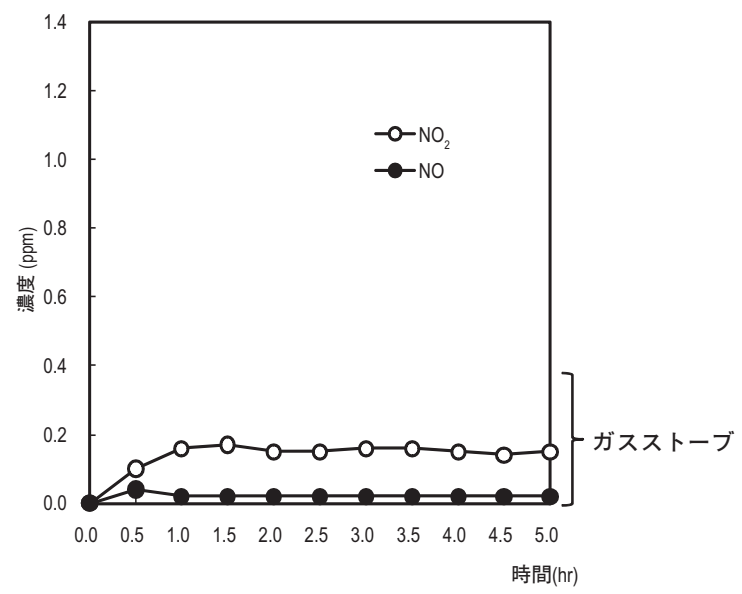

図1 各種暖房によるモデルルーム中のNOx濃度 
1990年代に入ると, VOCsを含めて室内污染調査 が盛んになされる様になってきた。1997年と1998年, 厚生労働省が居住環境中のVOCsの大規模な全国実 態調査を実施した。44種VOCsの室内と室外の濃度 比較した結果, ほとんどのVOCsは室内が室外に比 べ高值であった(表3)。

新築と中古(築14年)の居室のVOCs濃度は, 新築 ではデカン類, トルエン, パラジクロロベンゼン, $\alpha$-ピネン等が高い傾向であった(表4, 松村 1998) ${ }^{9)}$ 。

北海道, 夏 (1998), 冬 (1999)の両季節, 従来型の 建材タイプ住宅と, ほとんど化学物質を含まない建 材の住宅のVOCs濃度を計測・比較した(中井ら， 1999) ${ }^{10)}$ 。トルエン濃度はほとんど化学物質を含ま ない建材を利用した住宅では半減しているが，それ 以外のVOCs濃度は従来型夕イプとほとんど变わら ない結果であった(表5)。

室内污染の原因の解明のため, 比較的気密性の高 いモデルルーム容積 $45 \mathrm{~m}^{3}$ (幅 $2.8 \mathrm{~m}$, 奥行き $6.4 \mathrm{~m}$, 高 さ2.6m)を用いて，6種類の暖房器具使用により発 生する化学物質濃度を計測した (児玉ら $1988^{11)}$,

Arashidani et al 1996 ${ }^{12}$ ) 。なお, 換気操作なしの場 合で, 換気回数 $0.3 \sim 1.4$ 回/hrであった。CO濃度は反 射式石油ストーブ, 都市ガスでは, ビル衛生管理基 準 $(10 \mathrm{ppm})$ を若干超えるレベルであり(図2), $\mathrm{CO}_{2}$ 濃 度は, 電気ストーブを除くすべての暖房器具でビル 衛生管理基準1000ppmを大きく上回っていた（図2）。 $\mathrm{NO}_{2}$ 濃度は電気ストーブを除く, 石油系, ガス系 ストーブのすべてで，一般環境基準 (0.06ppm)を超 す濃度レベルとなった。また，NO濃度は対流式石 油ストーブと石油ファンヒーターで $\mathrm{NO}_{2}$ 濃度に比べ, 2倍以上の高值であった(図3)。

ホルムアルデヒド濃度は室外に比べ, いずれの暖 房器具とも高いレベルで, 特にプロパンガス及び都 市ガスストーブで高值であったが, 室内環境基準 （80ppb）以下であった(図4)。

室内におけるホルムアルデヒド発生は暖房器具使

表3 全国実態調查成績一室内濃度の最大値, 最小値, 平均値

\begin{tabular}{|c|c|c|c|c|}
\hline & 物質名 & 最小值 $\left(\mu \mathrm{g} / \mathrm{m}^{3}\right)$ & 最大值 $\left(\mu \mathrm{g} / \mathrm{m}^{3}\right)$ & 平均値 $\left(\mu \mathrm{g} / \mathrm{m}^{3}\right)$ \\
\hline \multirow[t]{13}{*}{ 脂肪族炭化水素 } & ヘキサン & 0.5 & 138 & 7.4 \\
\hline & ヘプタン & 0.4 & 427 & 7.7 \\
\hline & オクタン & 0.4 & 477 & 11.5 \\
\hline & ノナン & 0.4 & 590 & 20.9 \\
\hline & デカン & 0.4 & 572 & 23.1 \\
\hline & ウンデカン & 0.4 & 268 & 14.6 \\
\hline & ドデカン & 0.4 & 232 & 9.5 \\
\hline & トリデカン & 0.4 & 182 & 7.3 \\
\hline & テトラデカン & 0.4 & 75 & 5.7 \\
\hline & ペンタデカン & 0.4 & 42 & 2 \\
\hline & ヘキサデカン & 0.3 & 59.8 & 1.3 \\
\hline & 2,4-ジメチルペンタン & 0.3 & 61.5 & 1.2 \\
\hline & 2,2,4-トリメチルペンタン & 0.3 & 38.3 & 0.9 \\
\hline \multirow{10}{*}{ 芳香族炭化水素 } & ベンゼン & 0.4 & 65.8 & 5.9 \\
\hline & トルエン & 0.3 & 2,375 & 93.3 \\
\hline & エチルベンゼン & 0.2 & 723 & 21.6 \\
\hline & m,p-キシレン & 0.2 & 717 & 26.7 \\
\hline & 0-キシレン & 0.2 & 380 & 11.5 \\
\hline & スチレン & 0.1 & 183 & 4.5 \\
\hline & 1,3,5-トリメチルベンゼン & 0.1 & 1085 & 9.6 \\
\hline & 1,2,4-トリメチルベンゼン & 0.1 & 2988 & 29 \\
\hline & 1,2,3-トリメチルベンゼン & 0.1 & 155 & 5.8 \\
\hline & 1,2,4,5-テトラメチルベンゼン & 0.1 & 122 & 1.5 \\
\hline \multirow[t]{2}{*}{ テンベン類 } & $\alpha$-ピネン & 0.1 & 296 & 12.9 \\
\hline & リモネン & 0.1 & 690 & 26.5 \\
\hline \multirow[t]{10}{*}{ ハロゲン類 } & ジクロロメタン & 0.4 & 154 & 7.5 \\
\hline & トリクロロエチレン & 0.2 & 1,864 & 7.9 \\
\hline & テトラクロロエチレン & 0.2 & 83.5 & 1.8 \\
\hline & クロロホルム & 0.4 & 154 & 2.1 \\
\hline & 1,1,1-トリクロロエタン & 0.2 & 58.3 & 1.7 \\
\hline & 1,2-ジクロロエタン & 0.2 & 61 & 1.2 \\
\hline & 1,2-ジクロロプロパン & 0.2 & 37.4 & 1.1 \\
\hline & p-ジクロロベンゼン & 0.3 & 6,058 & 128 \\
\hline & 四塩化炭素 & 0.4 & 283 & 3.6 \\
\hline & クロロジブロモメタン & 0.2 & 490 & 5.3 \\
\hline \multirow[t]{2}{*}{ エステル類 } & 酢酸エチル & 0.5 & 149 & 9 \\
\hline & 酢酸ブチル & 0.3 & 441 & 10.3 \\
\hline \multirow[t]{7}{*}{ アルコールアルデヒドケトン類 } & アセトン & 2.6 & 361 & 32.3 \\
\hline & メチルエチルケトン & 0.7 & 129 & 6.6 \\
\hline & メチルイソブチルケトン & 0.3 & 473 & 7.3 \\
\hline & エタノール & 5 & 2476 & 281 \\
\hline & n-ブタノール & 0.5 & 82.6 & 5.1 \\
\hline & ノナナール & 0.7 & 73.9 & 5.9 \\
\hline & デカナール & 0.7 & 46.6 & 3.1 \\
\hline
\end{tabular}


表4 新築と中古住宅のVOCs濃度比較

\begin{tabular}{|c|c|c|c|}
\hline & 化学物質 $\left(\mu \mathrm{g} / \mathrm{m}^{3}\right)$ & 新築住宅 & "中古（築14年） \\
\hline \multirow[t]{11}{*}{ 脂肪族 } & ヘキサン & $2.6 \sim 9.4$ & 3.7 \\
\hline & ヘプタン & $0.7 \sim 61.3$ & 1.6 \\
\hline & オクタン & $1.3 \sim 7.5$ & - \\
\hline & デカン & $5.5 \sim 167$ & 3.8 \\
\hline & ウンデカン & $37.7 \sim 1449$ & 2.3 \\
\hline & ドデカン & $2.6 \sim 1770$ & - \\
\hline & トリデカン & $3.7 \sim 135$ & - \\
\hline & テトラデカン & $2.9 \sim 17.1$ & 2.4 \\
\hline & ペンタデカン & $0.7 \sim 16.9$ & 1.5 \\
\hline & ヘキサデカン & $1.6 \sim 2.8$ & - \\
\hline & 2,4-ジメチルペンタン & $6.9 \sim 9.8$ & - \\
\hline \multirow[t]{9}{*}{ 芳香族 } & ベンゼン & $1.3 \sim 6.9$ & 4.7 \\
\hline & トルエン & $1.9 \sim 2216$ & 31.4 \\
\hline & m-エチルトルエン & $1.6 \sim 139$ & - \\
\hline & p-エチルトルエン & $5.5 \sim 65.1$ & - \\
\hline & o-エチルトルエン & $32.6 \sim 35.2$ & - \\
\hline & 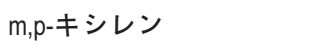 & $9.2 \sim 941$ & - \\
\hline & 1,3,5-トリメチルベンゼン & $1.1 \sim 34.6$ & - \\
\hline & 1,2,4-トリメチルベンゼン & $4.2 \sim 213$ & - \\
\hline & エチルベンゼン & $2.9 \sim 766$ & 4.3 \\
\hline \multirow[t]{7}{*}{ ハロゲン類 } & クロロホルム & $3.5 \sim 24.4$ & 7.3 \\
\hline & 1,1,1-トリクロロエタン & $5.5 \sim 6.5$ & - \\
\hline & 四塩化炭素 & $5.7 \sim 18.4$ & - \\
\hline & テトラクロロエチレン & 5.7 & - \\
\hline & ジクロロメタン & 8.7 & - \\
\hline & p-ジクロロベンゼン & $38.7 \sim 455$ & - \\
\hline & トリクロロエチレン & 2.3 & 8.1 \\
\hline エステル & 䣷酸エチル & $2.5 \sim 105$ & 4.1 \\
\hline \multirow[t]{3}{*}{ アルデヒド類 } & 1-ノナナール & $11.8 \sim 571$ & 5.1 \\
\hline & 1-デカナール & $4.7 \sim 5.2$ & 6.9 \\
\hline & アセトン & $16.9 \sim 69.1$ & - \\
\hline \multirow[t]{5}{*}{ アルコール } & メタノール & $7.6 \sim 7.9$ & - \\
\hline & 1-プロパノール & 109.1 & - \\
\hline & 2-プロパノール & $2.7 \sim 30.9$ & - \\
\hline & 1-ブタノール & $1.4 \sim 6.5$ & - \\
\hline & エタノール & 12.4 & 3.2 \\
\hline \multirow[t]{2}{*}{ テルペン類 } & $\alpha$-ピネン & $525 \sim 3910$ & - \\
\hline & TVOC & $1427 \sim 14155$ & 5.4 \\
\hline
\end{tabular}

（松村，建築雑誌，113(1421), 18～19, 1998）

表5 住宅内の揮発性有機化合物の濃度 $\left(\mu \mathrm{g} / \mathrm{m}^{3}\right)$

\begin{tabular}{|c|c|c|c|c|}
\hline & \multicolumn{2}{|r|}{ 住宅 } & \multirow[b]{2}{*}{ P值 } \\
\hline & & 従来型の建材 & ほとんど化学物質を含まない建材 & \\
\hline \multirow[t]{2}{*}{ トルエン } & 1998冬 & $36.5(29.1 \sim 91.9)$ & $19.2(14.5 \sim 30.7)$ & 0.02 \\
\hline & 1999夏 & $24.4(14.3 \sim 64.8)$ & $6.3(4.4 \sim 7.2)$ & $<0.01$ \\
\hline \multirow[t]{2}{*}{ ベンゼン } & 1998冬 & $2.2(2.0 \sim 3.0)$ & $4.4(3.3 \sim 5.5)$ & $<0.01$ \\
\hline & 1999夏 & $1.2(0.8 \sim 1.3)$ & $1.2(0.8 \sim 1.4)$ & 0.83 \\
\hline \multirow[t]{2}{*}{ エチルベンゼン } & 1998冬 & $8.9(4.0 \sim 12.0)$ & $5.4(3.8 \sim 11.5)$ & 0.31 \\
\hline & 1999夏 & $3.6(2.7 \sim 9.7)$ & $1.6(1.4 \sim 3.7)$ & 0.04 \\
\hline \multirow[t]{2}{*}{ o-キシレン } & 1998冬 & $4.5(2.0 \sim 6.6)$ & $5.8(2.5 \sim 7.8)$ & 0.29 \\
\hline & 1999夏 & $1.0(0.9 \sim 1.8)$ & $1.6(1.0 \sim 3.0)$ & 0.04 \\
\hline \multirow[t]{2}{*}{ m,p- キシレン } & 1998冬 & $14.6(8.6 \sim 18.6)$ & $16.9(8.9 \sim 26.1)$ & 0.38 \\
\hline & 1999夏 & $6.6(4.7 \sim 14.8)$ & $3.1(2.8 \sim 6.0)$ & 0.04 \\
\hline \multirow[t]{2}{*}{ スチレン } & 1998冬 & $3.6(2.6 \sim 5.6)$ & $2.6(1.0 \sim 3.7)$ & 0.04 \\
\hline & 1999夏 & $8.8(5.9 \sim 19.2)$ & $4.1(3.6 \sim 7.8)$ & 0.04 \\
\hline \multirow[t]{2}{*}{ p-ジクロロベンゼン } & 1998冬 & $14.2(0.6 \sim 63.8)$ & $1.8(0.8 \sim 13.9)$ & 0.55 \\
\hline & 1999夏 & $2.9(1.5 \sim 4.9)$ & $1.3(0.7 \sim 2.0)$ & 0.06 \\
\hline
\end{tabular}



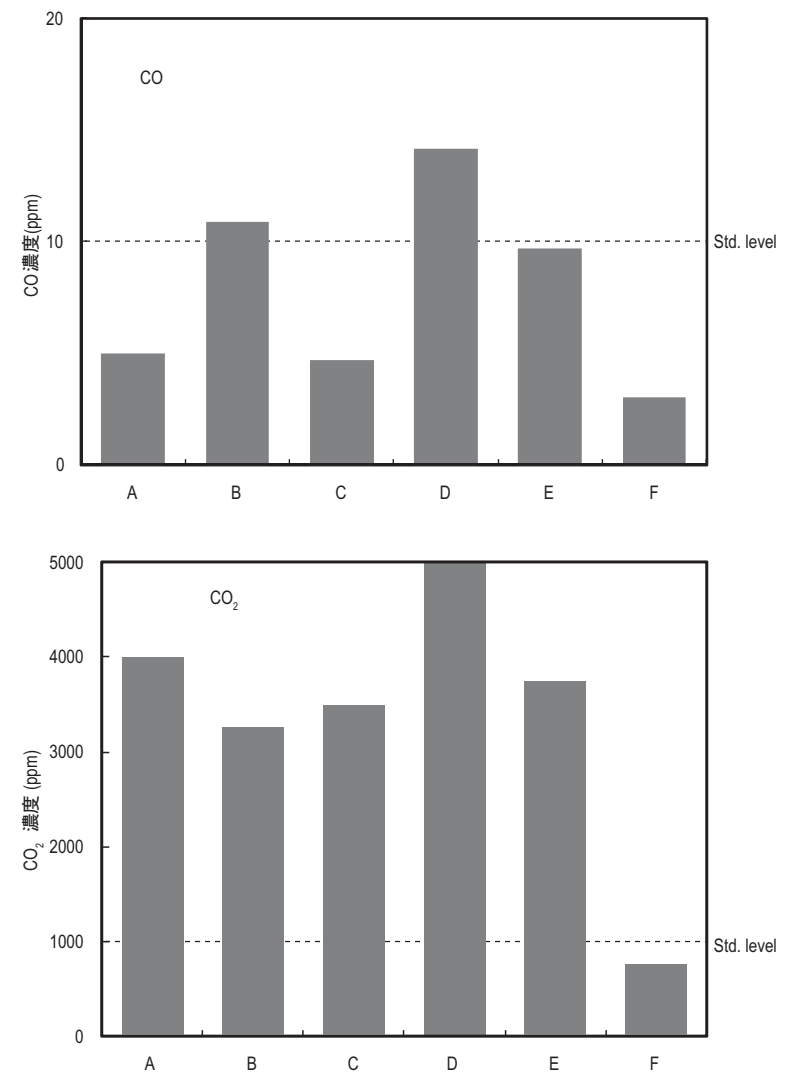

図2 各種暖房器具使用によるCO及びCO $\mathrm{O}_{2}$ 濃度比較 A:Convention oil heater B:Reflexion oil heater C:Oil fan-heater D:Gas heater E:Propane gas heater F:Electric heater

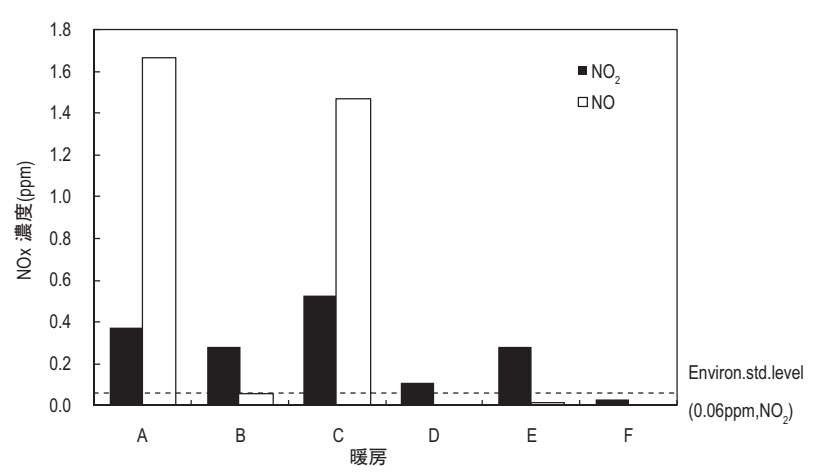

図3各種暖房器具によるモデルルーム内のNOx 濃度比較

$A=$ Convection oil heater, $B=$ Reflexion oil heater,

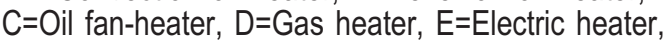
$\mathrm{F}=$ Electric heater

用のみでなく, 濃度上昇における建材からの放散も 考慮する必要あある。

暖房器具使用による浮遊粒子数は増加する傾向が あるが，重量濃度は室外の濃度レベルとほぼ同等で, ビル衛生管理基準 $\left(0.15 \mathrm{mg} / \mathrm{m}^{3}\right)$ の $1 / 3$ 以下であり，ま た多環芳香族炭化水素は, 石油系暖房器具使用時に 他の暖房, 室外に比べ, 高い傾向であったが, ベン ゾ(a)ピレン濃度はすべて $2 \mathrm{ng} / \mathrm{m}^{3}$ 以下の低いレベル

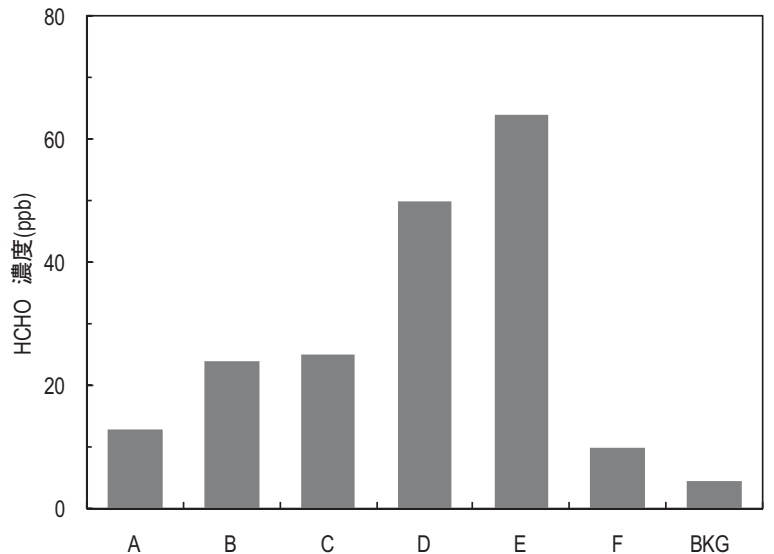

図4 各種暖房器具によるモデルルーム内の ホルムアルデヒド濃度比較

A:Convention oil heater B:Reflexion oil heater C:Oil fan-heater D:Gas heater E:Propane gas heater $F:$ Electric heater BKG:Back ground

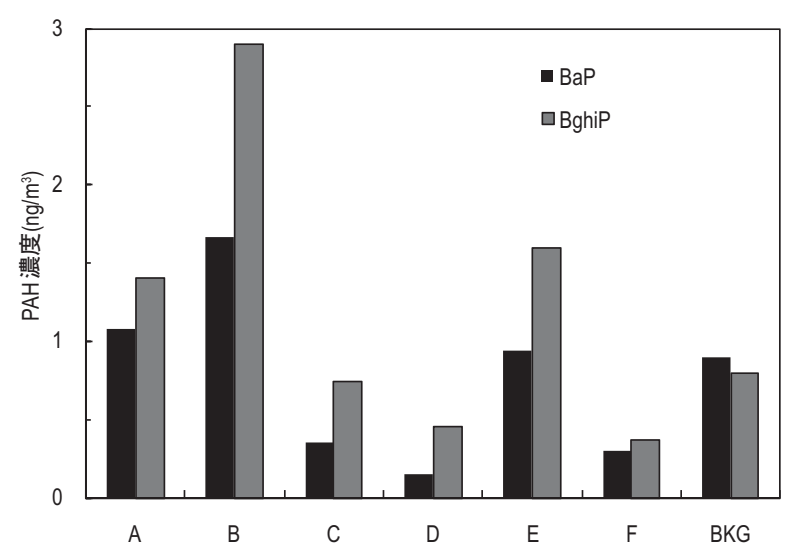

図5 各種暖房器具によるモデルルーム内の 多環芳香族炭化水素濃度比較

であった(図5)。

多くの研究者が測定した室内のホルムアルデヒド 平均濃度は松村ら $(1983)^{13)}$, 新田ら $(1986)^{14)}$, 上月 ら $(1997)^{15)}$, の報告書に示されている。これらは, 1980年から2000年頃までの調査結果でありこの当時 新築などの室内で, ホルムアルデヒド濃度は室内環 境基準值80ppbを超す值がしばしば認められている。 1970年代, 松村ら (1983) ${ }^{13)}$ により報告された各種 建築物内のホルムアルデヒド濃度を測定年日，1時 間值をむとにまとめたものを表6に示す。一般住居 Cでは, 建築後3 月, 子供部屋 $290 \mathrm{ppb}$, 居間 197 $\mathrm{ppb}$, 台所 $107 \mathrm{ppb}$ と高濃度で, ここの住人からは呼 吸器疾患等の訴えがなされた。

1990年より今日までの, 室内の化学物質の調査は 極めて多く，活発なる調査がなされてきている。 1990年以前に比べて，いずれの化学物質とも濃度は 
表6＼cjkstart各種建築物内のホルムアルデヒド濃度 (1983年)

\begin{tabular}{|c|c|c|}
\hline 建築物 & 測定年 & $\begin{array}{c}\text { 1時間值 } \\
(\mathrm{ppb})\end{array}$ \\
\hline \multirow{2}{*}{ デパート } & 1979 & $2-79$ \\
\hline & 1981 & $29-89$ \\
\hline \multirow{2}{*}{ スーパーマーケット } & 1979 & $32-65$ \\
\hline & 1981 & $4-65$ \\
\hline 一般住居 A & 1979 & $8-45$ \\
\hline $\mathrm{A}$ & 1981 & $12-125$ \\
\hline B & 1979 & $136-172$ \\
\hline $\mathrm{C}$ & 1981 & $107-290$ \\
\hline \multirow{3}{*}{$\begin{array}{ll}\text { オフィスビル } & \text { 事務所 } \\
& \text { 喫煙室 } \\
\text { 公共図書館 } & \end{array}$} & 1979 & $1-41$ \\
\hline & 1981 & $40-63$ \\
\hline & 1981 & $28-35$ \\
\hline $\begin{array}{l}\text { 公共図書館 } \\
\text { オフィスビル, 本屋 }\end{array}$ & 1981 & $47-71$ \\
\hline 映画館 & 1981 & $1-35$ \\
\hline 病院 & 1981 & $13-25$ \\
\hline 大規模家具店 & 1981 & 60 \\
\hline \multirow{2}{*}{$\begin{array}{ll}\text { プレハブ 新築 } \\
\\
\text { 築7年 }\end{array}$} & 1979 & $40 \sim>200$ \\
\hline & 1978 & $2-67$ \\
\hline 都市大気(東京千代田区) & 1980 & $1-38$ \\
\hline
\end{tabular}

我が国で2000年以前調査された主要なホルムアル デヒド濃度を表7に示す (上月ら 1997) ${ }^{15)}$ 。多くの調 査で, 20 $60 \mu \mathrm{g} / \mathrm{m}^{3}$ で, 室外濃度の約 10 倍程度高值 である。しかし，建築後の年数が短い場合，築 $1 \sim 3$ カ月では，300〜 $500 \mu \mathrm{g} / \mathrm{m}^{3}$ に達し，築1年後で70〜 $120 \mu \mathrm{g} / \mathrm{m}^{3}$ になるとが注目される。

富士市・夏季 (1999)，一般家庭内より，11種類の アルデヒド・ケトンを検出・定量した（雨谷ら， 2000 ${ }^{17)}$ 。すべてのアルデヒド・ケトン濃度は, 屋 外より室内濃度 (表8)が高く, ホルムアルデヒドは 新築住宅内が高く，室内濃度指針值を超えた家庭は 2 家庭 $(10 \%)$ であり, 室内の 10 種類のアルデヒド濃 度間には有意な相関が認められた。

生活環境中のたばこ喫煙污染評価としてニコチン 個人曝露濃度を計測し，種々生活環境中でニコチン 曝露濃度は1.76〜 $83.1 \mu \mathrm{g} / \mathrm{m}^{3}$ の範囲にあった(村松, $1985)^{18)}$ 。
低減してきている。

ホルムアルデヒド個人曝露濃度は, 建築後 14 年の住居で主婦が0.009ppm, 最高は建築 1 力月経過で個人住宅の主 婦が $0.259 \mathrm{ppm}$ であった。ホルムアル デヒド濃度は，建築直後の住宅で，1 時間值 $0.1 \mathrm{ppm}$ 以上の高濃度がしばし ば認められた(村松，1986) )。 $^{8)}$

居住環境で，1980年代に計測された 室内ホルムアルデヒド濃度は松村 $(1987)^{16)}$ がまとめて報告している。我 が国で最高值は築1 カ月後の鉄筋コン クリートの住宅居間 $804 \mu \mathrm{g} / \mathrm{m}^{3}(643 \mathrm{ppb})$, 外国ではモデルホーム $3,550 \mu \mathrm{g} / \mathrm{m}^{3}$ (2,840ppb)であった。

\section{表7 日本の各調査によるホルムアルデヒドの室内平均気中濃度}

\begin{tabular}{|c|c|c|c|c|}
\hline 建造物 & 測定件数 & $\begin{array}{l}\text { 濃度 }\left(\mu \mathrm{g} / \mathrm{m}^{3}\right) \\
\text { 範囲 (平均値) }\end{array}$ & 築後年月数 & 文献 \\
\hline \multirow{3}{*}{ 鉄筋共同住宅 } & 2 & 59 79（69） & 9ヶ月 & \multirow{3}{*}{ 松村ら（1985） } \\
\hline & 1 & 119 & 1年 & \\
\hline & 20 & $20 \sim 28 \quad(25)$ & 1年6ヶ月 & \\
\hline 一般住宅 & 1 & 516 & 9ヶ月 & 山本 (1994) \\
\hline \multirow{3}{*}{ 一般住宅 } & 13 & $246 \sim 467 \quad(320)$ & 3ヶ月 & \multirow{3}{*}{ 三谷ら（1985) } \\
\hline & 13 & $37 \sim 92(52)$ & 1年 & \\
\hline & 24 & $25 \sim 71 （ 50 ）$ & 4年 & \\
\hline \multirow{3}{*}{ 鉄筋住宅 } & 1 & 497 & 1ヶ月 & \multirow{3}{*}{ 松村（1991） } \\
\hline & 1 & 123 & 1年 & \\
\hline & 1 & 107 & 2年 & \\
\hline 事務所ビル & 8 & $12 \sim 41 \quad(24)$ & & \multirow{2}{*}{ 三谷ら（1985) } \\
\hline スーパーマーケット & 15 & $10 \sim 60(30)$ & & \\
\hline デパート & & $3 \sim 109$ & & \multirow{2}{*}{ 松村（1991） } \\
\hline 図書館 & & $34 \sim 43$ & & \\
\hline 学校 & 12 & $7 \sim 57(26)$ & & 松村ら（1992） \\
\hline
\end{tabular}

表8＼cjkstart富士市・夏季の室内アルデヒド類濃度

\begin{tabular}{|c|c|c|c|c|c|c|c|c|c|c|}
\hline & \multicolumn{3}{|c|}{ Arithmetic } & \multicolumn{3}{|c|}{ Geometric } & \multirow[b]{2}{*}{$\operatorname{Max}$} & \multirow[b]{2}{*}{ Min } & \multirow[b]{2}{*}{ Max/Min } & \multirow{2}{*}{$\begin{array}{l}\text { Percentage } \\
\text { determined }\end{array}$} \\
\hline & mean & & std & mean & & std & & & & \\
\hline Formaldehyde & 39.9 & \pm & 33.0 & 27.8 & \pm & 2.47 & 110 & 7.35 & 14.9 & $100 \%$ \\
\hline Acetaldehyde & 14.3 & \pm & 9.9 & 11.3 & \pm & 2.02 & 35.1 & 4.21 & 8.32 & $100 \%$ \\
\hline Propanal & 1.60 & \pm & 1.16 & 1.30 & \pm & 1.89 & 4.24 & 0.512 & 8.28 & $100 \%$ \\
\hline i-Butanal & 0.375 & \pm & 0.315 & 0.256 & \pm & 2.70 & 1.17 & $<0.037$ & $>31$ & $95 \%$ \\
\hline n-Butanal & 0.490 & \pm & 0.324 & 0.399 & \pm & 1.96 & 1.39 & 0.099 & 14.1 & $100 \%$ \\
\hline Ethylmethylketone & 1.24 & \pm & 1.19 & 0.662 & \pm & 3.89 & 3.98 & $<0.055$ & $>72$ & $95 \%$ \\
\hline Crotonaldehyde & 0.408 & \pm & 0.263 & 0.334 & \pm & 1.93 & 1.10 & 0.111 & 9.94 & $100 \%$ \\
\hline i-Pentanal & 0.602 & \pm & 0.328 & 0.515 & \pm & 1.81 & 1.26 & 0.172 & 7.33 & $100 \%$ \\
\hline n-Pentanal & 0.933 & \pm & 1.17 & 0.591 & \pm & 2.49 & 5.35 & 0.139 & 38.4 & $100 \%$ \\
\hline Benzaldehyde & 0.919 & \pm & 0.634 & 0.663 & \pm & 2.80 & 2.27 & $<0.039$ & $>58$ & $95 \%$ \\
\hline n-Hexanal & 4.12 & \pm & 4.91 & 2.69 & \pm & 2.37 & 21.4 & 0.907 & 23.6 & $100 \%$ \\
\hline
\end{tabular}




\section{2000 年以降}

全国規模で室内空気中の化学物質の実態に関する 調査が，安藤ら $(2004)^{19}$ によってなされた。これは 3 年間に渡って全国約1,000家屋について約160化学 物質, 150,000 に上るデー夕を得た。3力年連続で 10 $\mu \mathrm{g} / \mathrm{m}^{3}$ 以上の中央值濃度を示した化学物質は, トル エンで14〜 $30 \mu \mathrm{g} / \mathrm{m}^{3}$, エタノール $100 \sim 770 \mu \mathrm{g} / \mathrm{m}^{3}$, リ モネン $10 \sim 12 \mu \mathrm{g} / \mathrm{m}^{3}$ であり，いずれかの年度で $10 \mu \mathrm{g} /$ $\mathrm{m}^{3}$ 以上の中央值濃度を示した化学物質は, $\mathrm{n}$-テトラ デカン $12 \mu \mathrm{g} / \mathrm{m}^{3}, \quad \alpha$-ピネンで $8 \sim 21 \mu \mathrm{g} / \mathrm{m}^{3}$, アセトン 4〜16 $\mu \mathrm{g} / \mathrm{m}^{3}$ 等であった。また, $1 \sim 10 \mu \mathrm{g} / \mathrm{m}^{3}$ の化学物 質は約 20 化学物質が認められた。3年間を通して 10 $\mu \mathrm{g} / \mathrm{m}^{3}$ 以上の濃度を超過した化学物質は 12 化学物質, いずれかの年度で $10 \mu \mathrm{g} / \mathrm{m}^{3}$ 以上の濃度の高い值もの は22種も存在していた。化学物質群ごとの割合は, テルペン類 $30 \%$, 脂肪族炭化水素類 $23 \%$, 芳香族炭 化水素類 $19 \%$, 八ロゲン化炭化水素類13\%等であっ た。発癌性物質のベンゼンが認められ, 開始年度は $3 \mu \mathrm{g} / \mathrm{m}^{3}$ であったが, 最終年度では $2 \mu \mathrm{g} / \mathrm{m}^{3}$ まで低下し て低減化していることがみられた。しかし，依然之 して $2 \mu \mathrm{g} / \mathrm{m}^{3}$ 付近の值を示し, 最大值が $20 \sim 60 \mu \mathrm{g} / \mathrm{m}^{3}$ と年度を問わず高い值を示す居住環境が存在し, 特 定の室内環境では発生源が室内に存在することが示 唆された。室内・外の発生源の指標となるI/O比が2 以下のあのは，20化学物質も存在していた。これら の化合物質の中には, ベンゼン, イソオクタンなど の自動排出ガスに起因する化学物質が認められ, 室 外環境からの進入の可能性が認められた。

居室と子供部屋では, 対象122化学物質のうち 100 化学物質以上の $90 \%$ が検出された。化学物質群ごと の比較では「子供部屋」では脂肪族炭化水素が23成分 検出され，その他芳香族炭化水素 (18)，アルコール 類(11), 八ロゲン化炭化水素(10), 追加13成分 (8), 環状炭化水素, テルペン類及びエステル類 (7)が検 出された。平成14及び15年度で実施した居間と子供 部屋の調査では, ほとんどの化学物質で極めて高い 相関関係が認められ, 子供部屋の室内空気はその居 間の空気と同様な質と考えられた。しかしながら， 平成13年度においては，テルペン類が子供部屋で極 端に少なかったのに対し，八ロカーボン類は極端に 高い結果が得られ, 注意して監視していく必要があ る。

特定建築物の空気環境調査として, 美術館・博物 館内の空気污染調査 (秋山ら，2008) 20) では, VOCs
が31種類とアルデヒド類 2 種類を定量したが, 特に 問題となる濃度レベルではなかった（表 $9 ，$ 表10)。

大型ショッピングセンター内の空気污染調査 (真 鍋ら, 2008 $)^{211}$ では店舗内の陳列の違いにより化学 物質濃度に比較的大きい差か認められた(表11)。

茨城県つくば市を中心に新築住宅と新築マンショ ン各1戸(2003年)のVOCs測定の実施でメメチルェチ ルケトンが高濃度 (442ppb)で, それ以外のVOCsは 比較的低い濃度レベルで，4ヶ月後にはほとんど10 $\mathrm{ppb}$ 以下と低い濃度レベルに減少した $(\text { 表12 })^{22)}$ 。

特殊な環境として国産乗用車101台中からVOCs を275物質の同定，242物質を定量した（吉田ら， 2005) ${ }^{23)}$ 。

化学物質類ごとにまとめると, 脂肪族炭化水素類 が総VOCs中の $42 \%$ 占め, 最も高く, 次に芳香族 炭化水素類が $19 \%$ であり, その他アルコール類, 含 窒素化合物の濃度が高く, これらが車内の污染に寄 与している(表13)。

神奈川県内の新築集合住宅, 竣工後 1 年間に渡っ て化学物質濃度計測した結果 (大塚, 2002) ${ }^{24)}$, ホル ムアルデヒド濃度は $75 \sim 512.5 \mu \mathrm{g} / \mathrm{m}^{3}$, 年平均 $212.5 \mu \mathrm{g}$ $/ \mathrm{m}^{3}$ で, 室内指標值 $\left(100 \mu \mathrm{g} / \mathrm{m}^{3}\right)$ の約5 倍, 年平均值で 約2倍高值であり, 押入れやタンス等の発生源由来 である。また夏季に高值で室温の影響を受けている (表14)。

トルエンは $67 \sim 2700 \mu \mathrm{g} / \mathrm{m}^{3}$, 年平均值は $660 \mu \mathrm{g} / \mathrm{m}^{3}$ で室内指針值 $\left(260 \mu \mathrm{g} / \mathrm{m}^{3}\right)$ の約 10 倍, 年平均值が約 2.5 倍の高值である。パラジクロロベンゼン, エチ ルベンゼン, スチレン, クロロピリボス等は室内指 針值以下であった。

新築未入居戸建 (アパート含む 40 件)の室内化学物 質濃度を計測した (松田，2003 ${ }^{25)}$ 。VOCsの気中の 最も高かった物質は, $\alpha$-ピネン $\left(7872 \mu \mathrm{g} / \mathrm{m}^{3}\right)$, 次い でリモネン, トルエン, キシレン, 酶酸エチル, エ チルベンゼンであった。最大值が最も高かった物質 はアセトン $(0.37 \mathrm{ppm})$ で, 次いでメチルエチルケト ン，ホルムアルデヒド，プロピオンアルデヒドであ る。ホルムアルデヒド, アセトアルデヒド, ベンズ アルデヒドの発生源として木質建材由来と考えられ る(表15，表16)。

一定地域の新築住宅の自覚症状と室内化学物質濃 度調查を実施した (岸ら, 2004 $)^{26)}$ 。その結果, 厚生 労働省の室内指針值を超えた住宅は96軒中ホルムア ルデヒドが 13 軒, アセトアルデヒドは3軒, トルエ 
表9 美術館内のVOC濃度 (ppb)

\begin{tabular}{lccccc}
\hline \hline & 最小 $\sim$ 最大 & 室内平均 & 個人曝露 & 室外 & 室内/室外 \\
\hline Toluene & N.D. $\sim 0.77$ & 0.39 & 0.05 & N.D. & - \\
Ethylbenzene & $0.30 \sim 2.43$ & 1.04 & 0.51 & 0.17 & 6.13 \\
m/p-Xylene & $0.16 \sim 1.07$ & 0.54 & 0.30 & 0.09 & 5.98 \\
o-Xlene & $0.16 \sim 0.86$ & 0.45 & 0.26 & 0.06 & 7.56 \\
1,2,3-Trimethylbenzene & $0.10 \sim 1.24$ & 0.46 & 0.24 & 0.11 & 4.14 \\
1,2,4-Trimethylbenzene & N.D. $\sim 0.39$ & 0.13 & 0.05 & N.D. & - \\
1,3,5-Trimethylbenzene & $0.03 \sim 0.35$ & 0.13 & 0.06 & 0.06 & 2.21 \\
Stylene & $0.04 \sim 0.20$ & 0.10 & 0.10 & N.D. & - \\
Hepatne & $0.11 \sim 2.14$ & 0.52 & 0.69 & 0.19 & 2.75 \\
Octane & $0.11 \sim 1.24$ & 0.31 & 0.22 & N.D. & - \\
Nonane & $0.11 \sim 1.78$ & 0.48 & 0.26 & 0.09 & 5.32 \\
Decane & $1.47 \sim 4.56$ & 2.57 & 4.25 & 2.36 & 1.09 \\
Undecane & $0.32 \sim 1.82$ & 0.81 & 0.80 & N.D. & - \\
$\alpha$-Pinene & $0.04 \sim 25.1$ & 3.23 & 2.54 & N.D. & - \\
Limonene & N.D. $\sim 1.78$ & 0.20 & 0.14 & N.D. & - \\
1-Butanol & N.D. $\sim 2.53$ & 0.47 & 0.30 & 0.21 & 2.22 \\
2-Ethyl-1-Hexanol & N.D. $\sim 1.30$ & 0.33 & 0.14 & N.D. & - \\
Methylethylketone & $0.29 \sim 1.32$ & 0.78 & 0.85 & 0.56 & 1.40 \\
Methylisobuthylketone & N.D. $\sim 0.30$ & 0.08 & N.D. & 0.15 & 0.52 \\
p-Dichlorobenzene & $0.10 \sim 0.91$ & 0.32 & 0.56 & 0.11 & 2.90 \\
Trichloroethylene & N.D. $\sim 0.18$ & 0.06 & N.D. & 0.18 & 0.33 \\
Tetrachloroethylene & N.D. $\sim 0.28$ & 0.08 & 0.51 & N.D. & - \\
1,1,1-Trichloroethane & N.D. $\sim 0.04$ & 0.01 & 0.00 & N.D. & - \\
Dibromochloromethane & N.D. $\sim 0.02$ & N.D. & 0.00 & N.D. & - \\
Chloroform & $0.04 \sim 0.37$ & 0.20 & 0.52 & 0.04 & 5.07 \\
Ethyl Acetate & N.D. $\sim 0.97$ & 0.32 & 0.03 & 0.43 & 0.75 \\
Buthyl Acetate & N.D. $\sim 11.4$ & 1.35 & N.D. & N.D. & - \\
TVOC & $7.05 \sim 20.77$ & 13.38 & N.C & 9.42 & 1.42 \\
\hline
\end{tabular}

表10 博物館内のVOC濃度 (ppb)

\begin{tabular}{|c|c|c|c|c|c|}
\hline & 最小 〜 最大 & 室内平均 & 個人曝露 & 室外 & 室内/室外 \\
\hline Benzene & N.D. $\sim 1.06$ & 0.66 & N.D. & N.D. & - \\
\hline Toluene & N.D. $\sim 50.08$ & 15.02 & 8.01 & 3.10 & 4.85 \\
\hline Ethylbenzene & $1.20 \sim 5.24$ & 2.82 & 8.42 & 0.63 & 4.48 \\
\hline $\mathrm{m} / \mathrm{p}$-Xylene & $0.52 \sim 4.10$ & 1.35 & 3.11 & 0.27 & 5.01 \\
\hline o-Xlene & $0.27 \sim 1.78$ & 0.70 & 1.82 & 0.18 & 3.90 \\
\hline 1,2,3-Trimethylbenzene & $0.07 \sim 0.19$ & 0.12 & 0.29 & 0.07 & 1.76 \\
\hline 1,2,4-Trimethylbenzene & $0.31 \sim 0.70$ & 0.48 & 1.04 & 0.26 & 1.85 \\
\hline 1,3,5-Trimethylbenzene & $0.07 \sim 0.18$ & 0.11 & 0.23 & 0.07 & 1.63 \\
\hline Stylene & $0.54 \sim 15.01$ & 4.34 & 7.45 & N.D. & - \\
\hline Hepatne & N.D. $\sim 1.84$ & 0.38 & 0.15 & N.D. & - \\
\hline Octane & N.D. $\sim 0.39$ & 0.11 & 1.19 & N.D. & - \\
\hline Nonane & $0.02 \sim 0.30$ & 0.15 & 0.64 & 0.06 & 2.43 \\
\hline Decane & N.D. $\sim 7.96$ & 1.97 & N.D. & N.D. & - \\
\hline Undecane & $1.12 \sim 3.23$ & 2.17 & 7.56 & 1.57 & 1.38 \\
\hline 2,4-Dimethylpentane & N.D. $\sim 2.67$ & 0.68 & 1.12 & N.D. & - \\
\hline$\alpha$-Pinene & $1.29 \sim$ N.D. & 0.25 & N.D. & N.D. & - \\
\hline Limonene & N.D. $\sim 0.33$ & 0.14 & 0.55 & N.D. & - \\
\hline 1-Butanol & N.D. $\sim 1.81$ & 0.35 & N.D. & N.D. & - \\
\hline 2-Ethyl-1-Hexanol & $0.26 \sim 1.45$ & 0.57 & 1.15 & N.D. & - \\
\hline Methylethylketone & $0.83 \sim 7.10$ & 3.15 & 2.78 & 1.09 & 2.89 \\
\hline Methylisobuthylketone & N.D. $\sim 0.74$ & 0.29 & 0.48 & N.D. & - \\
\hline Carbon Tetrachloride & N.D. $\sim 0.14$ & 0.04 & 0.23 & N.D. & - \\
\hline 1,2-Dichloroethane & N.D. $\sim 0.03$ & N.D. & N.D. & N.D. & - \\
\hline p-Dichlorobenzene & N.D. $\sim 1.38$ & 0.41 & 4.72 & 0.10 & 4.13 \\
\hline Trichloroethylene & N.D. $\sim 0.04$ & 0.02 & 0.08 & N.D. & - \\
\hline Tetrachloroethylene & $0.01 \sim 0.30$ & 0.11 & 0.34 & 0.02 & 5.50 \\
\hline 1,1,1-Trichloroethane & N.D. $\sim 0.12$ & 0.03 & 0.14 & N.D. & - \\
\hline Dibromochloromethane & N.D. $\sim 0.05$ & 0.01 & 0.00 & N.D. & - \\
\hline Chloroform & N.D. $\sim 1.20$ & 0.51 & 1.93 & 0.66 & 0.77 \\
\hline Ethyl Acetate & N.D. $\sim 20.57$ & 8.00 & 28.12 & N.D. & - \\
\hline Buthyl Acetate & N.D. $\sim 0.09$ & 0.03 & 0.00 & N.D. & - \\
\hline TVOC & $20.89 \sim 90.08$ & 40.08 & N.C & 8.80 & 4.56 \\
\hline
\end{tabular}


表11 大型ショッピングセンターの污染状況調査

\begin{tabular}{|c|c|c|c|c|c|c|c|c|c|c|}
\hline \multirow{2}{*}{ 分類 } & \multirow{2}{*}{ 測定物質 } & \multicolumn{4}{|c|}{ 室内濃度 $\left(\mu \mathrm{g} / \mathrm{m}^{3}\right)$} & \multicolumn{4}{|c|}{ 室外濃度 $\left(\mu \mathrm{g} / \mathrm{m}^{3}\right)$} & \multirow{2}{*}{$\begin{array}{l}\text { 室内/ } \\
\text { 室外 }\end{array}$} \\
\hline & & $\mathrm{N}$ & 最小 & 最大 & 幾何平均値 & $\mathrm{N}$ & 最小 & 最大 & 幾何平均値 & \\
\hline \multirow{9}{*}{$\begin{array}{l}\text { 芳香族炭化 } \\
\text { 水素類 }\end{array}$} & ベンゼン & 125 & $<1.5$ & 13.5 & $<1.5$ & 4 & N.D & N.D & N.D & - \\
\hline & トルエン & 125 & $<0.7$ & 88.5 & 8.3 & 4 & 7.2 & 7.8 & 7.5 & 1.1 \\
\hline & エチルベンゼン & 125 & $<0.6$ & 101.0 & $4.8^{* *}$ & 4 & 1.6 & 2.0 & 1.8 & 2.8 \\
\hline & m/p-キシレン & 125 & $<0.9$ & 67.5 & $3.5^{* *}$ & 4 & 1.6 & 2.1 & 1.8 & 2.0 \\
\hline & o-キシレン & 125 & $<2.7$ & 58.9 & $2.9^{*}$ & 4 & N.D & N.D & N.D & 2.2 \\
\hline & 1,2,3,-リメチルベンゼン & 125 & $<4.2$ & 14.1 & $<4.2$ & 4 & N.D & N.D & N.D & - \\
\hline & 1,2,4,-リメチルベンゼン & 125 & $<3.5$ & 16.0 & $<3.5$ & 4 & N.D & N.D & N.D & - \\
\hline & 1,3,5,-リメチルベンゼン & 125 & $<2.8$ & 21.7 & $<2.8$ & 4 & N.D & N.D & N.D & - \\
\hline & スチレン & 125 & $<4.3$ & 116.0 & $<4.3$ & 4 & N.D & N.D & N.D & - \\
\hline \multirow{6}{*}{$\begin{array}{l}\text { 脂肪族炭化 } \\
\text { 水素類 }\end{array}$} & ヘプタン & 125 & $<1.8$ & 49.2 & $2.4^{*}$ & 4 & N.D & N.D & N.D & 2.6 \\
\hline & オクタン & 125 & $<1.7$ & 44.3 & 1.8 & 4 & N.D & N.D & N.D & 2.1 \\
\hline & ノナン & 125 & $<2.1$ & 29.1 & 1.6 & 4 & N.D & N.D & N.D & 1.5 \\
\hline & デカン & 125 & $<2.0$ & 182.0 & $9.4^{*}$ & 4 & $<2.0$ & 4.1 & $<2.0$ & 9.2 \\
\hline & ウンデカン & 125 & $<8.1$ & 225.0 & 8.1 & 4 & N.D & N.D & N.D & 2.0 \\
\hline & 2,4-ジメチルペンタン & 125 & $<1.0$ & 3.8 & $<1.0$ & 4 & N.D & N.D & N.D & - \\
\hline \multirow{2}{*}{ テルペン類 } & a-ピネン & 125 & $<5.4$ & 129.0 & $6.1^{*}$ & 4 & N.D & N.D & N.D & 2.3 \\
\hline & リモネン & 125 & $<5.8$ & 229.0 & $11.3^{* *}$ & 4 & N.D & N.D & N.D & 3.9 \\
\hline \multirow{2}{*}{ アルコール類 } & 1-ブタノール & 125 & $<1.0$ & 29.1 & $2.9^{* *}$ & 4 & $<1.0$ & 1.0 & $<1.0$ & 5.9 \\
\hline & 2-エチル-1-ヘキサノール & 125 & $<1.3$ & 69.2 & $6.2^{* *}$ & 4 & N.D & N.D & N.D & 9.3 \\
\hline \multirow{2}{*}{ ケトン類 } & メチルエチルケトン & 125 & $<1.3$ & 8.2 & $2.9^{* *}$ & 4 & $<1.3$ & 1.4 & $<1.3$ & 4.5. \\
\hline & メチルイソブチルケトン & 125 & $<2.3$ & 6.6 & $<2.3$ & 4 & N.D & N.D & N.D & - \\
\hline \multirow{9}{*}{ 含ハロゲン類 } & 四塩化炭素 & 125 & $<1.2$ & 5.2 & $<1.2$ & 4 & N.D & N.D & N.D & - \\
\hline & 1,2-ジクロロエタン & 125 & $<0.8$ & 9.1 & $<0.8$ & 4 & N.D & N.D & N.D & - \\
\hline & 1,2-ジクロロプロパン & 125 & N.D & N.D & N.D & 4 & N.D & N.D & N.D & - \\
\hline & パラジクロロベンゼン & 125 & $<1.1$ & 54.5 & 2.1 & 4 & $<1.1$ & 1.7 & 1.2 & 1.7 \\
\hline & トリクロロエチレン & 125 & $<1.4$ & 1.9 & $<1.4$ & 4 & N.D & N.D & N.D & - \\
\hline & テトラクロロエチレン & 125 & $<1.1$ & 83.3 & 1.6 & 4 & N.D & N.D & N.D & 2.9 \\
\hline & 1,1,1-トリクロロエタン & 125 & N.D & N.D & N.D & 4 & N.D & N.D & N.D & - \\
\hline & ジブロモクロロメタン & 125 & N.D & N.D & N.D & 4 & N.D & N.D & N.D & - \\
\hline & クロロホルム & 125 & $<1.4$ & 4.1 & $<1.4$ & 4 & N.D & N.D & N.D & - \\
\hline \multirow{2}{*}{ エステル類 } & 酢酸エチル & 125 & $<2.2$ & 30.5 & $4.1^{* *}$ & 4 & N.D & N.D & N.D & 3.8 \\
\hline & 酢酸ブチル & 125 & $<3.1$ & 7.5 & $<3.1$ & 4 & N.D & N.D & N.D & - \\
\hline \multicolumn{2}{|l|}{ TVOC } & 125 & 38.6 & 1288.0 & $95.2^{* *}$ & 4 & 45.7 & 50.0 & 47.1 & 2.0 \\
\hline \multicolumn{2}{|c|}{ ホルムアルデヒド } & 125 & 11.4 & 38.5 & $22.8^{* *}$ & 4 & 7.9 & 18.0 & 12.0 & 1.9 \\
\hline \multicolumn{2}{|c|}{ アセトアルデヒド } & 125 & 5.9 & 23.7 & $10.7^{* \star *}$ & 4 & 1.3 & 2.0 & 1.7 & 6.3 \\
\hline
\end{tabular}

表12 2003年4月つくば市内住宅の化学物質測定結果 (ppb)

\begin{tabular}{|c|c|c|c|c|c|}
\hline & $\begin{array}{l}\text { リビンク } \\
\end{array}$ & $\begin{array}{l}\text { ダイニング } \\
\end{array}$ & 台所 & 屋外1 & 屋外2 \\
\hline ヘキサン & 1.39 & 1.54 & 1.74 & 0.01 & 0.26 \\
\hline 2,4-ジメチルペンタン & 0.29 & 0.35 & 0.36 & 0.05 & 0.00 \\
\hline ヘプタン & 1.40 & 2.33 & 2.54 & 0.12 & 0.09 \\
\hline オクタン & 1.75 & 2.66 & 2.94 & 0.06 & 0.05 \\
\hline ノナン & 4.18 & 5.51 & 6.25 & 0.12 & 0.00 \\
\hline デカン & 6.88 & 7.77 & 9.21 & 0.21 & 1.02 \\
\hline ウンデカン & 9.07 & 9.84 & 11.0 & 0.22 & 0.13 \\
\hline ベンゼン & 0.83 & 0.98 & 1.02 & 0.30 & 0.39 \\
\hline トルエン & 40.9 & 40.2 & 45.3 & 2.60 & 1.26 \\
\hline エチルベンゼン & 3.30 & 4.36 & 4.96 & 0.15 & 0.35 \\
\hline$m, p$-キシレン & 5.26 & 6.61 & 7.55 & 0.20 & 0.41 \\
\hline 0-キシレン & 3.55 & 4.56 & 5.36 & 0.11 & 0.09 \\
\hline スチレン & 0.54 & 0.65 & 0.69 & 0.28 & 0.34 \\
\hline 1,3,5-トリメチルベンゼン & 4.34 & 5.49 & 6.59 & 0.09 & 0.30 \\
\hline 1,2,4-トリメチルベンゼン & 27.0 & 35.0 & 42.8 & 0.29 & 0.16 \\
\hline 1,2,3-トリメチルベンゼン & 3.20 & 4.19 & 4.99 & 0.10 & 0.07 \\
\hline クロロホルム & 0.18 & 0.23 & 0.24 & 0.05 & 0.14 \\
\hline 1,2-ジクロロエタン & 0.15 & 0.15 & 0.15 & 0.05 & 0.00 \\
\hline 1,1,1-トリクロロエタン & 0.15 & 0.14 & 0.14 & 0.05 & 0.12 \\
\hline 四塩化炭素 & 0.17 & 0.15 & 0.12 & 0.07 & 0.10 \\
\hline 1,2-ジクロロプロパン & 0.85 & 0.70 & 0.13 & 0.06 & 0.02 \\
\hline トリクロロエチレン & 0.20 & 0.17 & 0.17 & 0.04 & 0.11 \\
\hline テトラクロロエチレン & 0.13 & 0.13 & 0.13 & 0.03 & 0.09 \\
\hline クロロジブロモメタン & 0.14 & 0.18 & 0.19 & 0.00 & 0.11 \\
\hline p-ジクロロベンゼン & 0.35 & 0.38 & 0.41 & 0.12 & 0.34 \\
\hline 酢酸エチル & 0.23 & 0.00 & 0.35 & 0.00 & 0.00 \\
\hline 酢酸ブチル & 3.32 & 4.14 & 4.64 & 0.09 & 0.00 \\
\hline メチルエチルケトン & 442 & 314 & 360 & 1.75 & 1.04 \\
\hline メチルイソブチルケトン & 1.60 & 2.85 & 3.14 & 0.12 & 0.00 \\
\hline 1-ブタノール & 2.77 & 3.81 & 4.45 & 0.50 & 0.74 \\
\hline$\alpha$-ピネン & 33.4 & 22.5 & 25.6 & 0.19 & 0.44 \\
\hline リモネン & 3.22 & 4.41 & 4.84 & 0.05 & 0.15 \\
\hline
\end{tabular}


表13 乗用車内の主要な化学物質濃度

\begin{tabular}{|c|c|c|c|c|}
\hline & \multicolumn{2}{|c|}{ 濃度 $\left(\mu \mathrm{g} / \mathrm{m}^{3}\right)$} & \multirow{2}{*}{$\begin{array}{c}\text { T-VOC(MS)濃度に } \\
\text { 占める割合 }(\%) \\
\text { 中央値 }\end{array}$} & \multirow[t]{2}{*}{ 指針値 } \\
\hline & 中央値 & （最小〜最大） & & \\
\hline Formaldehyde & 19 & $(7.5 \sim 61)$ & & 100 \\
\hline T-VOC(MS) (241) & 601 & $(136 \sim 3968)$ & & 400 \\
\hline 脂肪族炭化水素（70） & 258 & $(56 \sim 1977)$ & 42 & \\
\hline アルカン（42） & 224 & $(41 \sim 1720)$ & 37 & \\
\hline $\mathrm{n}$-Tetradecane & 7.6 & $(1.2 \sim 47)$ & 1.2 & 330 \\
\hline シクロアルカン（24） & 30 & $(5.9 \sim 294)$ & 4.9 & \\
\hline アルケン（2） & 2.3 & $(0.46 \sim 128)$ & 0.35 & \\
\hline シクロアルケン（2） & 0.48 & $(0.07 \sim 56)$ & 0.07 & \\
\hline 芳香族炭化水素類（49） & 112 & $(35 \sim 595)$ & 19 & \\
\hline Toluene & 33 & $(12 \sim 356)$ & 5.5 & 260 \\
\hline Ethylbenzene & 7.2 & $(2.2 \sim 59)$ & 1.1 & 3800 \\
\hline Styrene & 2.6 & $(0 \sim 79)$ & 0.39 & 220 \\
\hline Xyrene & 14 & $(4.6 \sim 89)$ & 2.1 & 870 \\
\hline ハロゲン化物（8） & 10 & $(3.1 \sim 195)$ & 1.8 & \\
\hline p-Dichlorobenzene & 4.8 & $(0.75 \sim 179)$ & 0.72 & 240 \\
\hline テルペン類（12） & 9.1 & $(1.3 \sim 502)$ & 1.6 & \\
\hline エステル類（12） & 16 & $(3.3 \sim 233)$ & 2.4 & \\
\hline カルボニル化合物（10） & 31 & $(12 \sim 383)$ & 5.5 & \\
\hline アルデヒド（4） & 11 & $(3.3 \sim 35)$ & 1.7 & \\
\hline ケトン（6） & 22 & $(2.8 \sim 376)$ & 3.2 & \\
\hline その他（60） & 123 & $(18 \sim 1239)$ & 21 & \\
\hline アルコール・グリコール（18） & 42 & $(6.1 \sim 573)$ & 6.3 & \\
\hline キノン（2） & 14 & $(1.4 \sim 61)$ & 2.4 & \\
\hline フェノール（3） & 15 & $(0.64 \sim 150)$ & 2 & \\
\hline エーテル（3） & 0.16 & $(0 \sim 1.6)$ & 0.02 & \\
\hline フラン（2） & 19 & $(0.35 \sim 25)$ & 0.28 & \\
\hline リン酸エステル（9） & 0.44 & $(0.02 \sim 8.5)$ & 0.07 & \\
\hline アジピン酸エステル（3） & 0.21 & $(0 \sim 13)$ & 0.04 & \\
\hline フタル酸エステル（11） & 0.78 & $(0.09 \sim 6.6)$ & 0.12 & \\
\hline 含窒素化合物（9） & 36 & $(36 \sim 1043)$ & 6.6 & \\
\hline
\end{tabular}

表14 化学物質濃度 $\left(\mu \mathrm{g} / \mathrm{m}^{3}\right)$

\begin{tabular}{|c|c|c|}
\hline & 濃度( & $\left.\mathrm{g} / \mathrm{m}^{3}\right)$ \\
\hline & 範囲 & 年平均値 \\
\hline Formaldehyde $\left(\mu \mathrm{g} / \mathrm{m}^{3}\right)$ & & \\
\hline $\mathrm{HCHO}$ (indoor) & $75 \sim 512.5$ & 212.5 \\
\hline $\mathrm{HCHO}$ (outdoor) & N.D. $\sim 45$ & 22.5 \\
\hline Volatile organic compoun & $\left(\mu \mathrm{g} / \mathrm{m}^{3}\right)$ & \\
\hline Acetone & N.D. $\sim 49$ & 47 \\
\hline Methylethylketone & N.D $\sim 118$ & 53 \\
\hline Ethylacetate & N.D. $\sim 113$ & 37 \\
\hline Benzene & $0.06 \sim 14$ & 4.4 \\
\hline Methylisobuthylketone & N.D. $\sim 170$ & 33 \\
\hline Toluene & $67 \sim 2700$ & 660 \\
\hline Buthylacetate & $3.8 \sim 170$ & 40 \\
\hline Ethylbenzene & $12 \sim 1100$ & 300 \\
\hline m,p-Xylene & $27 \sim 1800$ & 430 \\
\hline o-Xylene & $7.2 \sim 600$ & 200 \\
\hline Styrene & $5.6 \sim 87$ & 33 \\
\hline a-Pinene & $160 \sim 500$ & 280 \\
\hline Decane & $0.85 \sim 460$ & 58 \\
\hline Tetradecane & N.D. $\sim 15$ & 4.3 \\
\hline 1,2,4-Trimethylbenzene & $0.8 \sim 320$ & 64 \\
\hline Limonene & $1.1 \sim 72$ & 29 \\
\hline p-Dichlorobenzene & N.D. $\sim 54$ & 15 \\
\hline
\end{tabular}

測定場所：リビングルーム 
表15 アルデヒド、ケトン類の住宅内濃度

\begin{tabular}{lccc}
\hline \hline & 最小 & 最大 & 平均 \\
\hline ホルムアルデヒド & 0.007 & 0.170 & 0.059 \\
アセトアルデヒド & 0.006 & 0.126 & 0.053 \\
アセトン & 0.008 & 0.377 & 0.055 \\
アクロレイン & 0.000 & 0.015 & 0.001 \\
プロピオンアルデヒド & 0.000 & 0.157 & 0.013 \\
クロトンアルデヒド & 0.000 & 0.007 & 0.001 \\
メチルエチルケトン & 0.002 & 0.251 & 0.027 \\
メタクロレイン & 0.000 & 0.015 & 0.001 \\
n-ブチルアルデヒド & 0.000 & 0.012 & 0.003 \\
イソブチルアルデヒド & 0.000 & 0.000 & 0.000 \\
ベンズアルデヒド & 0.000 & 0.091 & 0.009 \\
パレルアルデヒド & 0.000 & 0.021 & 0.007 \\
イソバレルアルデヒド & 0.000 & 0.000 & 0.000 \\
m-toruアルデヒド & 0.000 & 0.000 & 0.000 \\
ヘキサアルデヒド & 0.000 & 0.065 & 0.022 \\
\hline
\end{tabular}

\section{表16 揮発性有機化合物の住宅内濃度}

\begin{tabular}{|c|c|c|c|}
\hline & & 最大 & 平均 \\
\hline 酢酸エチル & 12 & 945 & 143 \\
\hline ベンゼン & 0 & 28 & 6 \\
\hline トルエン & 1 & 1272 & 244 \\
\hline エチルベンゼン & 0 & 913 & 83 \\
\hline o-,m-,p-キシレン & 0 & 1047 & 63 \\
\hline スチレン & 0 & 497 & 69 \\
\hline パラジクロロベンゼン & 0 & 93 & 6 \\
\hline ノナナール & 1 & 421 & 23 \\
\hline ノナン & 0 & 122 & 19 \\
\hline デカン & 1 & 460 & 67 \\
\hline ウンデカン & 0 & 609 & 64 \\
\hline ドデカン & 0 & 325 & 29 \\
\hline トリデカン & 0 & 777 & 24 \\
\hline テトラデカン & 0 & 346 & 21 \\
\hline ペンタデカン & 0 & 28 & 2 \\
\hline ヘキサデカン & 0 & 15 & 1 \\
\hline$\alpha$-ピネン & 0 & 7872 & 810 \\
\hline$\beta$-ピネン & 1 & 197 & 34 \\
\hline リモネン & 1 & 3318 & 132 \\
\hline
\end{tabular}

表17 居間の化学物質濃度 (96軒)

\begin{tabular}{|c|c|c|c|c|c|}
\hline & Mean & & Min & & Max \\
\hline $\mathrm{HCHO}$ & 70.0 & & 8.1 & - & 146.9 \\
\hline $\mathrm{CH}^{3} \mathrm{CHO}$ & 16.3 & $<$ & 11.7 & - & 45.8 \\
\hline 2,4-dimethylpentane & 4.4 & $<$ & 4.2 & - & 48.0 \\
\hline Butanol & 15.3 & $<$ & 4.6 & - & 190.2 \\
\hline Heptane & 2.3 & $<$ & 4.1 & - & 8.3 \\
\hline Metyhylisobutylketone & 5.9 & $<$ & 3.8 & - & 44.1 \\
\hline Toluene(42軒) & 325.5 & $<$ & 3.0 & - & 3104.7 \\
\hline Tetra-chloroethylene & 5.1 & $<$ & 3.9 & - & 46.9 \\
\hline Buthylacetate & 14.8 & $<$ & 4.4 & - & 142.8 \\
\hline Ethylbenzene & 18.7 & $<$ & 3.9 & - & 278.1 \\
\hline Styrene & 13.1 & $<$ & 4.7 & - & 171.3 \\
\hline Nonane & 9.7 & $<$ & 4.8 & - & 85.5 \\
\hline Alpha-pinene & 27.5 & $<$ & 4.6 & - & 218.9 \\
\hline P-dichlorobenzene & 26.7 & $<$ & 3.8 & - & 1028.9 \\
\hline Limonene & 25.0 & $<$ & 4.0 & - & 138.8 \\
\hline Undecane & 7.2 & $<$ & 5.3 & - & 48.2 \\
\hline Nonanal & 5.7 & $<$ & 4.6 & - & 45.4 \\
\hline Xylene & 26.0 & $<$ & 8.2 & - & 180.0 \\
\hline Trimethylbenzene & 14.5 & $<$ & 12.2 & - & 97.8 \\
\hline Total VOC $1 \ddagger$ & 482.6 & & 43.0 & & 3277.7 \\
\hline Total VOC 2抽 & 221.9 & & 41.5 & & 1211.0 \\
\hline
\end{tabular}

ンは19軒(42軒中)，パラジクロロベンゼンは2軒で あり，エチルベンゼン，スチレン，キシレンは指針 值を超える值はなかった(表17)。

ホルムアルデヒド，アセトアルデヒド濃度とシッ クハウス症状との関連は認められなかった。しかし トルエンと酢酸ブチルは皮膚症状，パラジクロロベ ンゼンは鼻症状と有意に関連していた。

東京近郊 新築住宅(1996 2001, 戸建23，集合 12)の化学物質濃度調査の結果 (大貫 ${ }^{27}$ ), 2001, 表 18), ホルムアルデヒド, トルエン, p-ジクロロベ ンゼンの最大值は指針值を超え特にトルエンは8倍 以上である。

近年に建築された住宅ほよ゙，HCHO濃度低下が見 られ，1999年以降は，その傾向が著しく，指針值以 上の居室はなかった(表19)。

これは1997年に指針值が設定されたことにより， $\mathrm{HCHO}$ 低減化の対策が充分に取られている結果であ る。

VOCsの指針值は2000年及び2001年に設定され， VOCsの低減対策が充分でなく, トルエンでは指針 值以上の濃度の居室が多数あった。

瀧川の報告 $(2004)^{28)}$ によると, 近年, 一般家屋内 の化学物質濃度は減少傾向であるが，2003年の調査 では，VOCsで指針值を超過しているのは 0 2.2\% とほとんどないが，トルエン，キシレン，スチレン の最高濃度はそれぞれ $1,432 \mu \mathrm{g} / \mathrm{m}^{3}, 1,269 \mu \mathrm{g} / \mathrm{m}^{3}, 894$ $\mu \mathrm{g} / \mathrm{m}^{3}$ と指針值を超過している(表20)。

室内のホルムアルデヒド及びアセトアルデヒドで 指針值を超過しているのはそれぞれ $5 \%$ 程度 (最大 $221 \mu \mathrm{g} / \mathrm{m}^{3}$ ) と $10 \%$ 程度 (最大 $306 \mu \mathrm{g} / \mathrm{m}^{3}$ ) である(表21)。

SHS症状と化学物質濃度との関係では，指針值以 下であ自覚症状のある例が存在するなど，なお不明 な点が多い。

\section{5. 室内環境と健康影響}

シックハウス症候群，化学物質過敏症に影響を及 ぼす化学物質の研究は進んできているが，力ビなど のハウスダストによると考えられる小児喘息などの 問題は未だ残っている。

室内環境とヒト健康影響を調査した最近のいくつ かの調査について紹介する。

内山ら $(2003)^{29)}$ は全国から, 層化2段無作為抽出 した満20才以上の男女 4000 人を対象として Millerら $(1999)^{30)}$ によって開発された「Quick Environmental 
表18 築後6 カ月以内の室内化学物質濃度 (全49室)

\begin{tabular}{cccccc}
\hline \hline & \multicolumn{5}{c}{ 濃度 $\left(\mu \mathrm{g} / \mathrm{m}^{3}\right)$} \\
化学物質 & 最小 & 最大 & 平均値 & 中央値 & 指針値 \\
\hline ホルムアルデヒ & 5.9 & 141 & 40.9 & 26.9 & 80 \\
トルエン & 0.56 & 595 & 92.9 & 39.1 & 70 \\
エチルベンゼン & 0.69 & 22.6 & 6.1 & 4.9 & 880 \\
スチレン & 0.08 & 22 & 4.2 & 2.7 & 50 \\
P-ジクロロベンゼン & 0.12 & 207 & 22.8 & 1.6 & 40 \\
\hline
\end{tabular}

表19 調査年の化学物質の平均濃度

\begin{tabular}{cccccc}
\hline \hline & \multicolumn{5}{c}{ 濃度 $\left(\mu \mathrm{g} / \mathrm{m}^{3}\right)$} \\
化学物質 & 1996 & 1997 & 1998 & 1999 & 2000 \\
\hline 部屋数 $(\mathrm{n})$ & 6 & 10 & 4 & 2 & 8 \\
ホルムアルデヒド & 54.3 & 70.4 & 61 & 23 & 27.4 \\
トルエン & 11.7 & 143 & 27.2 & 19.8 & 138 \\
エチルベンゼン & - & 8.1 & 4.9 & 11.5 & 6.2 \\
キシレン & - & 16.9 & 8 & 19 & 11 \\
スチレン & 1.8 & 6.2 & 5.6 & 2.4 & 3.4 \\
P-ジクロロベンゼン & 0.5 & 17.6 & 1.3 & 29.4 & 23.3 \\
\hline
\end{tabular}

表20 全国及び主要都市の揮発性有機化合物濃度推移

\begin{tabular}{|c|c|c|c|c|}
\hline & \multicolumn{4}{|c|}{ 気中濃度 $\left(\mu \mathrm{g} / \mathrm{m}^{3}\right)$} \\
\hline & 2001年 & 2002年 & 2003年 & 2004年 \\
\hline \multicolumn{5}{|l|}{ 全国調査 } \\
\hline トルエン & 86.7 & 64.1 & 64.1 & - \\
\hline キシレン & 39.1 & 21.7 & 17.4 & - \\
\hline エチルベンゼン & 21.7 & 13 & 17.4 & - \\
\hline スチレン & 8.9 & 2.1 & 0.9 & - \\
\hline \multicolumn{5}{|l|}{ 地域別調査 } \\
\hline \multicolumn{5}{|l|}{ トルエン } \\
\hline 東京(n=44) & 39.6(夏) & 28.6(冬) & - & - \\
\hline 高知(n=6) & 36.1(冬) & - & - & - \\
\hline 宮城(n=5) & 10.8(冬) & - & - & - \\
\hline 岡山(n=84) & - & - & - & 11.2 \\
\hline \multicolumn{5}{|l|}{ エチルベンゼン } \\
\hline 東京(n=44) & 8.3(夏) & 4.5(冬) & - & - \\
\hline 高知(n=6) & 8.8(冬) & - & - & - \\
\hline 宮城(n=5) & 1.8(冬) & - & - & - \\
\hline 岡山(n=84) & - & - & - & 2.3 \\
\hline \multicolumn{5}{|l|}{ スチレン } \\
\hline 東京(n=44) & 5.2(夏) & 2.8(冬) & - & - \\
\hline 高知(n=6) & <0.3(冬) & - & - & - \\
\hline 宮城(n=5) & $\mathrm{ND}$ (冬) & - & - & - \\
\hline 岡山(n=84) & - & - & - & ND \\
\hline \multicolumn{5}{|l|}{ パラジクロロベンゼン } \\
\hline 東京(n=44) & 46.4(夏) & 14.1(冬) & - & - \\
\hline 高知(n=6) & 15.4(冬) & - & - & - \\
\hline 岡山(n=84) & - & - & - & 2.6 \\
\hline \multicolumn{5}{|l|}{ TVOC } \\
\hline 高知(n=6) & 238.0(冬) & - & - & - \\
\hline 宮城(n=5) & 337(冬) & - & - & - \\
\hline 岡山(n=84) & - & - & - & 97.8 \\
\hline ベンゾ(a)ピレン & & & & \\
\hline 東京(n=44) & . $.44 \mathrm{ng} / \mathrm{m}^{3}$ (夏) & $0.54 \mathrm{ng} / \mathrm{m}^{3}$ (冬) & - & - \\
\hline
\end{tabular}

\section{室内環境 [2009］}




\section{表21 全国及び主要都市の大気中アルデヒド類濃度推}

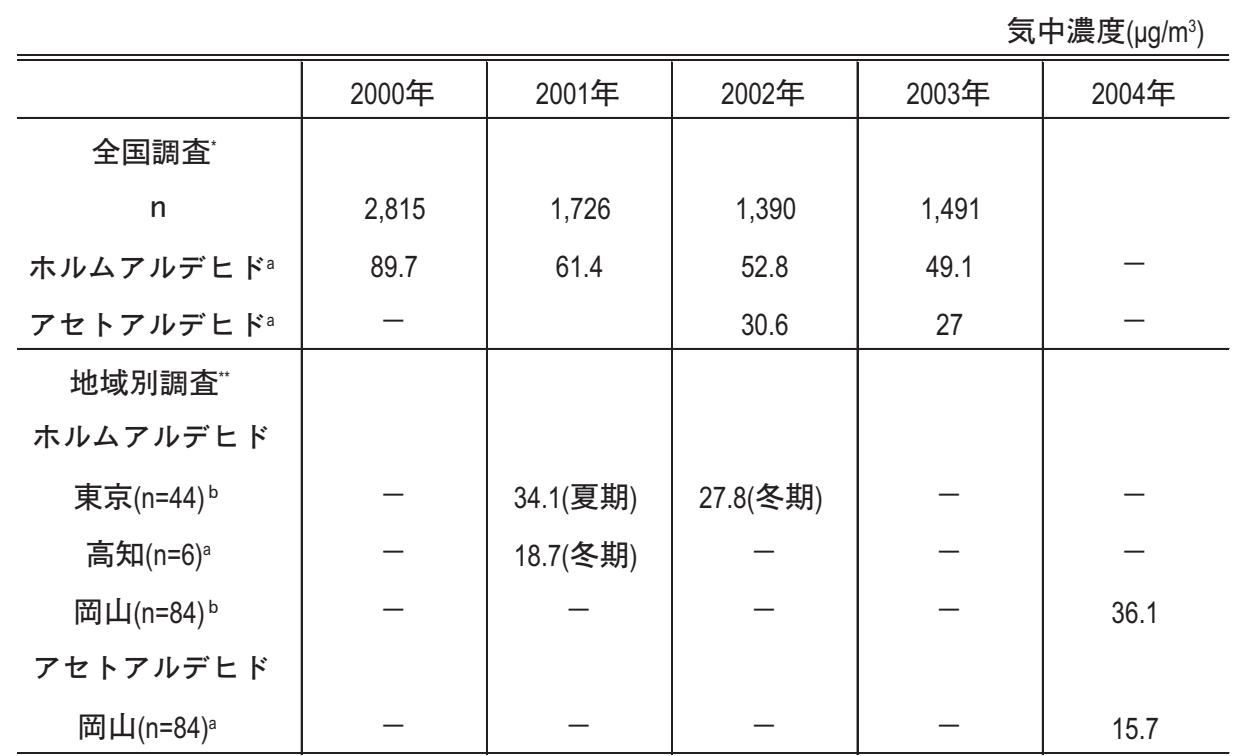

a平均値, ${ }^{b}$ 中央値

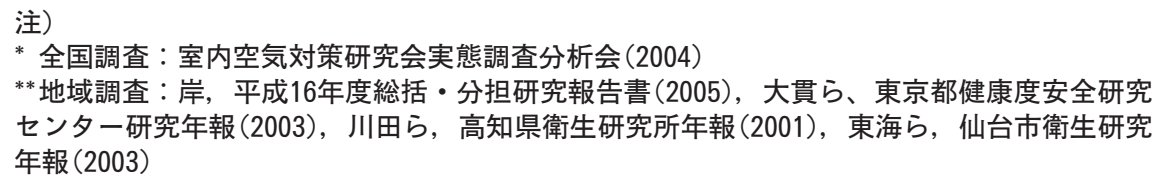

Exposure and Sensitivity Inventory(QEFSI)」を石川ら が日本人向けに改編した質問票を元にして新しく質 問票を作成した。このQEFSIは化学物質過敏症患者 の特徵ある調査項目である。

この調査票は「Chemical Exposure：化学物質曝露 による反応 (I)」「Other Exposures：その他の化学物 質による反応 (II) 」「Symptoms：症状 (III) 」の3 項目 でそれぞれ10問あり，計30問からなっている。

評価は3 項目でそれぞれカットオフ值 ( I : $\geqq 40$, II $: \geqq 40, \quad$ III $: \geqq 25)$ を超える点数である場合化学 物質に対する感受性の高い群としてスクリーニング する。

この調査で，3項目を満たしていたのは $0.74 \% ， 2$ 項目を満たしていたのは2.1\%と, Millerら(3 項目が $6.6 \%, 2$ 項目が $15.8 \%)$ の調查結果と比べ低いもので あった。

この調査で, 化学物質過敏症と診断されたと回答 したのは23名(回答者2,851人)で，そのうち実際に 同基準の3項目とも満たした人は 1 名, 化学物質過敏 症と診断された人の半数以上が基準を $1 つ$ 満たし ていなかった。

加藤ら (2007) ${ }^{31}$ は工場労働者2204名を対象者之 して(回答者数1986名)内山らが改良したQEESIを参
考にして作成した質問票を用いて化学物質過敏症の 調查を行った。この結果, 3項目のカットオフ值を

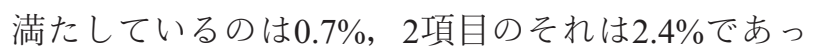
た。

真鍋ら $(2008)^{32}$ は, 特定建築物内で従来する従業 員410名 (回答率 $89.8 \%$ ) を対象にして内山らの質問 票を用いて，化学物質過敏症の調查を実施した。

QEESI質問票の3項目全ての基準を満たしている

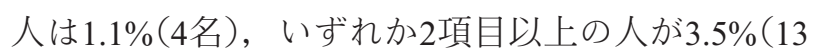
名)である。

この調査の中で, 化学物質過敏症と診断された人 は2名で, その中の1名が「症状」の項目でカットオフ 值を超過し, 他の1名は3項目ともカットオフ值以下 であった。

この調査結果は, 内山ら及び加藤らの調査結果と よく類似していたが, Miller ${ }^{30)}, \mathrm{Meggs}^{333}$ 及び Krentzerら ${ }^{34)}$ の結果より低い結果であった。

その他岸ら $(2006)^{35)}$ が全国を対象に築6年目以内 の一戸建住宅 2,298 軒の居住者の症状アンケートと 居住空間調査を実施した。

その結果, シック八ウス症候群の症状とカビ臭が 有意に関連していた。環境要因の変化とシックハウ 又症候群との関連について, $\alpha$-ピネン, TVOCの 
減少はリスクを減し，2-ペンタン，リモネン， TVOCの増加がリスクを上げることを示した。

国外の報告ではW.J.Firk $(2007)^{36)}$, C.G.Bornehag ら $\left(2004^{37)}, 2005^{38)}\right)$ で, 前者は室内の結露・カビが 呼吸器系の症状の発現の危険性が高い, 後者の調査 では，児童の喘息や鼻炎などの症状は居住内の結露・ カビの発生と関連していると示した。

\section{6. おわりに}

室内環境研究は, 日本の産業構造の変化によるビ ル内の業種の増加, また生活スタイルの变化に伴っ て発生する健康影響, また快適な室内空間の構築に 関する研究が増加してきている。この問題を取り上 げている学会は, 大気環境学会が最も早く, 1986年 までは一般大気演題の中に含まれて発表されていた が，1987年に屋内污染としてのセッションが初めて 設けられ，6題の発表があった。今日まで毎年10〜2 5題の発表がなされてきている。特に, VOCs, アル デヒド類, 多環芳香族炭化水素などの化学物質の実 態，測定方法などの発表が主である。

大気環境学会以外の発表の場として, 室内環境学 会は1995年設立され, 室内研究の中心として活動を 始めた。この学会では実態調査, 測定技術, 低減対 策を中心に毎年約 160 題の発表がなされている。そ の他, 日本建築学会は, 演題数が多く, 化学物質, 温熱, 換気, 空調と幅広い研究発表である。空気清 浄とコンタミネーションコントロール研究は空調設 備, クリーンルームの設備関連, 空気調和・衛生工 学会など, その学会の研究目的によって, それぞれ 活発に活動がなされている。

国際的には参加国・参加者と屯最大の学会は, 3 年に1回開かれるIndoor Air Quality and Climateで, 2008年はコペンハーゲンで11回目が開催された。こ の国際会議は発表演題は700題を超し, そのうち日 本人は約 65 題と回をおうごとに増加し日本での室内 環境研究が，世界的レベルであることが同える。

今後, 臨床系, 工学系, 物理系など空気環境に関 連する研究者との共同研究などを踏まえて, 積極的 な室内環境の取り組みがなされることを願う。

\section{引用文献}

1）日本放送協会放送世論調查所編：昭和55年度国 民生活時間調査(1981).

2) J.L.Repace:Indoor air pollution, Environ. Internet,
$8: 21 \sim 26(1982)$.

3）長谷川利雄, 城戸勝義, 小猿和男 : 住宅内の空 気污染に関する研究一室内の窒素酸化物濃度を 中心にしてー，公害と対策，12，1192-1202 (1976).

4）松村年郎，村松學：室内空気中における窒素酸 化物濃度について，公害と対策，17，443-448 (1981).

5）柳沢幸雄, 西村肇 : 生活環境中濃度测定用 $\mathrm{NO}^{2}$ パーソナル・サンプラー, 大気污染学会誌, 15 , 316-323 (1980).

6）新田裕史, 横山泰彦, 三浦邦彦 他：都市オフィ 又勤労者の二酸化窒素個人暴露量に関する研究, 大気污染学会誌，16，277-284(1981).

7）松木秀明, 春日斉, 逢坂文夫 他: 喫煙および 二酸化窒素による室内污染の影響に関する冬期 之夏期の比較研究, 日本公衛誌, 32, 549-559 (1985).

8）村松學：室内空気污染に関する研究, 大気污染 学会誌, 21, 236-252(1986).

9）松村年郎：化学物質による室内空気污染につい て, 建築雑誌, vol.113, 18-19(1998).

10）中井里史, 高木裕司, 柳沢幸雄, 篠原直秀, 西 岡祐里佳, J Vallarino, J Spengler, 河合了, 前 田雅彦, 池田康也：北海道における室内空気環 境測定，室内環境学会総会講演集，82-83(1999).

11）览玉 泰：生活環境中における慢性閉塞性肺疾 患発症因子の解明に関する研究報告書, 公害健 康被害補償予防協会委託業務報告書, （1988）。

12) K. Arashidani, M. Yoshikawa, T. Kawamoto, K. Matsumoto, F. Kayama and Y. Kodama :Indoor Pollution from Heating, Industrial Health, 34, 205215(1996).

13）松村年郎, 村松學, 亀谷勝昭：室内空気污染に 関する研究(第3報) 一室内空気中のホルムアル デヒド濃度についてー, 日本公衛誌，30，303308 (1983).

14）新田祐史, 前田和甫：公衆衛生の課題としての 室内污染, 産業公害, 22, 464-468(1986).

15）上月千佳子，泉那彦：ホルムアルデヒドによる 屋内大気污染, Man \& Environ, 23(1)，34-40 (1997).

16）松村年郎：室内污染の現状と今後の方向，第28 回大気污染学会講演要旨集, 84-88(1987). 
17）雨谷敬史, 大浦健, 杉山智彦, 房家正博, 松下 秀鶴：富士市・夏季におけるアルデヒド類によ る室内外の污染実態調查, 室内環境学会誌, 3 (1), 35-43 (2000).

18）村松茂登彦，梅村節子：ニコチン個人曝露セン 夕ーの開発とその応用, 医学のあゆみ, 113(9), 595-600(1985).

19）安藤正典：化学物質過敏症等室内空気中化学物 質に係わる疾病と総化学物質の存在量の検討之 要因解明に関する研究, 厚生労働科学研究費補 助金がん予防等健康科学総合研究事業平成13 15年度 総合研究報告書, (2004).

20）秋山幸雄, 欅田尚樹, 加藤貴彦, 内山嚴雄, 山 野優子, 嵐谷奎一: 美術館・博物館内の空気污 染調査, 大気環境学会誌, 43, 6, 323-331 (2008).

21）真鍋龍治, 欅田尚樹, 加藤貴彦, 黒田嘉紀, 秋 山幸雄, 山野優子, 内山巌雄, 嵐谷奎一: 大型 店舗内の空気污染及び個人曝露調查, 日本衛星 学会誌, 63, 20-28(2008).

22）山口貴史, 鈴木香織, 江副優香, 中島大介, 藤 巻秀和, 後藤純尾 : 新築住宅に抢ける揮発性有 機化合物の経時変化について, 平成15年度室内 環境学会総会講演集, 178-179(2003).

23）吉田俊明, 松永一朗, 富岡公子, 熊谷信二 : 揮 発性有機化合物による乗用車室内空気の污染一 I .国産100車種に抢ける污染実態調査一，室内 環境学会誌，8，188-189(2005).

24）大塚建次, 松村年郎, 濱田実香：居住環境内に 打ける化学物質污染の実態調査, 室内環境学会 誌, 5, 23-35(2002).

25）松田俊一, 寺村明憲, 辻恭子, 原田裕久：新築 住宅におけるアルデヒド・ケトン類(15物質), $\operatorname{VOC}(19$ 物質)の気中濃度の現状, 6, 150-153 (2003).

26）岸玲子, 西條泰明, 佐田文宏 :「シックハウス 症候群」の自覚症状と関連する要因一北海道で の新築一般住宅を対象とした実態調査結果につ いて，室内空気質と健康影響，167-173(2004).

27）大貫文, 斎藤育江, 瀬戸博, 上原眞一, 鈴木孝 人: 室内環境学会誌, 新築住宅におけるホルム アルデヒド濃度及び揮発性有機化合物濃度の年 次推移, 4, 96-97(2001).

28）瀧川智子：化学物質による室内環境污染とシッ
クハウス症候群, 日本職業・災害医学会会誌, 54, 193-199(2006).

29）内山㩔雄, 村山留美子：QEESI調査票を用いた 化学物質過敏症の全国調査, 第44回大気環境学 会講演要旨集, 246-247(2003).

30) Miller $C$, Prihoda T. :The environmental exposure and sensitivity inventory (EESI):a standardized approach for measuring chemical introlerances for research and clinical application., Toxicol Ind Health., 15, 386-396(1999).

31）加藤貴彦, 黒田嘉紀, 小宮康裕 : 工場労働者に おける化学物質過敏状態の質問表調査, 産衛誌, 48, 98-99(2007).

32）真鍋龍治, 欅田尚樹, 加藤貴彦, 黒田嘉紀, 秋 山幸雄, 山野優子, 内山嗾雄, 嵐谷奎一: 特定 建築物で働く従業員の化学物質過敏症に関する 質問票調查, 日本衛生学雑誌, 63, 717-723 (2008).

33) Meggs W, Dunn K, Bloch R, Goodman P and Davidoff A.: Prevalence and nature of Allergy and chemical sensitivity in a general population., Arch environ health., 51, 275-282(1996).

34) Kreutzer R, Neutra RR and Lashuay N. :Prevalence of people reporting sensitivities to chemicals in a population-based survey., Am J Epidemiol. 150, 1-12(1999).

35）岸玲子：全国規模の疫学研究によるシックハウ スの実態と要因の解明, 健康科学総合研究成果 発表会(研究者向け)報告書, 14-19(2006).

36 W.J.Fisk et al.:Meta-analysis of the associations of respiratory health effects with dampness and mold in homes, Indoor Air, vol.17, vol.4, pp.284296(2007).

37) C.G.Bornehug et al.:Dampness in buildings and health (DBH):Report from an ongoing epidemiological investigation on the association between indoor environmental factors and health effects among children in Sweden, Indoor Air vol.14, supple. 7, pp.59-66(2004).

38) C.G.Bornehug et al.:Association between ventilation rates 390 Swedish homes and allergic symptoms in children, Indoor Air vol.15, No.4, pp.284-296(2005). 